\title{
Raman Microspectroscopy of Garnets from S-Fibulae from the Archaeological Site Lajh (Slovenia)
}

\author{
Saša Kos ${ }^{1}{ }^{1}$, Matej Dolenec ${ }^{2}$, Judita Lux ${ }^{3}$ and Sabina Dolenec ${ }^{4, *}$ \\ Geological Survey of Slovenia, 1000 Ljubljana, Slovenia; sasa.kos@geo-zs.si \\ 2 Department of Geology, Faculty of Natural Sciences and Engineering, University of Ljubljana, \\ 1000 Ljubljana, Slovenia; matej.dolenec@ntf.uni-lj.si \\ 3 Institute for the Protection of Cultural Heritage of Slovenia, 4000 Kranj, Slovenia; judita.lux@zvkds.si \\ 4 Slovenian National Building and Civil Engineering Institute, 1000 Ljubljana, Slovenia \\ * Correspondence: sabina.dolenec@zag.si
}

Received: 31 January 2020; Accepted: 2 April 2020; Published: 4 April 2020

\begin{abstract}
Garnets (19 pieces) of Late Antique S-fibulae from the archaeological site at Lajh-Kranj (Slovenia) were analysed with Raman microspectroscopy to obtain their mineral characteristic, including inclusion assemblage. Most garnets were determined as almandines Type I of pyralspite solid solution series; however, three garnets showed a higher $\mathrm{Mg}, \mathrm{Mn}$ and $\mathrm{Ca}$ contents and were determined as almandines Type II. Most significant Raman bands were determined in the range of $169-173 \mathrm{~cm}^{-1}\left(\mathrm{~T}\left(\mathrm{X}^{2+}\right)\right), 346-352 \mathrm{~cm}^{-1}\left(\mathrm{R}\left(\mathrm{SiO}_{4}\right)\right), 557-559 \mathrm{~cm}^{-1}\left(v_{2}\right), 633-637 \mathrm{~cm}^{-1}\left(v_{4}\right), 917-919 \mathrm{~cm}^{-1}$ $\left(v_{1}\right)$, and $1042-1045 \mathrm{~cm}^{-1}\left(v_{3}\right)$. Shifting of certain Raman bands toward higher frequencies was the result of an increase of the $\mathrm{Mg}$ content in the garnet composition, which also indicates the presence of pyrope end member in solid garnet solutions. Inclusions of apatite, quartz, mica, magnetite, ilmenite, as well as inclusions with pleochroic or radiation halo and tension fissures (zircon), were found in most of the garnets. Rutile and sillimanite were found only in garnets with the highest pyrope content. Spherical inclusions were also observed in two garnets, which may indicate the presence of melt or gas residues. The determined inclusion assemblage indicates the formation of garnets during medium- to high-grade metamorphism of amphibolite or granulite facies. According to earlier investigations of the garnets from Late Antique jewellery, the investigated garnets are believed to originate from India.
\end{abstract}

Keywords: garnets; inclusions; S-fibulae; Late Antiquity; provenance; Raman microspectroscopy; XRF spectroscopy

\section{Introduction}

The production of ornamented metal jewellery decorated with red garnets has a long history in both European and Eastern cultures, dating back to the 3rd century BC. Garnet-inlaid metalwork made in the "cloisonné" technique, became widely spread among Migration Period Germanic tribes during the Late Antique to Early Middle Ages (4th to 8th century AD), although, the manufacture of cloisonné jewellery supposedly originated from the East in the Black Sea region [1,2]. The investigation of geographical and geological origin of garnets using chemical and mineralogical characterisation is and remains the subject of many studies, from the perspective of understanding the deposits of minerals and trade routes that linked them to the rest of the world, since large amounts of gemstones have been used in jewellery production [2-10].

The determination of the structure, composition and physical properties of minerals from archaeological artefacts is difficult since they should not be compromised. In this case, non-destructive analytical methods can be used. Chemical analysis is obtained by various analytical techniques 
(particle-induced X-ray emission/particle-induced gamma-ray emission-PIXE/PIGE, scanning electron microscopy with energy dispersive $X$-ray spectroscopy-SEM/EDS, X-ray fluorescence (XRF) spectroscopy, etc.), although they are sometimes insufficient to define the nature of the crystal and some are even destructive, expensive and time-consuming. The crystal structure can be determined by complementary techniques such as Raman spectroscopy, of which advantages are that it is rapid, requires little or no sample preparation and above all it is non-contact and non-destructive [11-13].

Garnets are a complex group of nesosilicate minerals with the general chemical formula $\mathrm{X}_{3} \mathrm{Y}_{2}\left(\mathrm{SiO}_{4}\right)_{3}$, where $\mathrm{X}$ sites are filled by either $\mathrm{Fe}^{2+}, \mathrm{Mg}^{2+}, \mathrm{Ca}^{2+}$ or $\mathrm{Mn}^{2+}$ ions and $\mathrm{Y}$ sites by $\mathrm{Al}^{3+}$, $\mathrm{Fe}^{3+}, \mathrm{Cr}^{3+}, \mathrm{Ti}^{3+}$ or $\mathrm{V}^{3+}$ ions [14]. Also, $\mathrm{Si}^{4+}$ is commonly substituted with $\mathrm{Al}^{3+}, \mathrm{Fe}^{3+}$ and $\mathrm{Ti}^{3+}$ [11]. The crystal structure of garnets is composed of the $\mathrm{SiO}_{4}$ tetrahedron and $\mathrm{YO}_{6}$ octahedron, which are bonded by an oxygen atom and thus form distorted dodecahedral $\mathrm{XO}_{8}$ cells [15]. Due to similar ionic radii, ionic charges and chemical affinity of present metallic cations, cation exchanges are common in garnets, thereby forming solid solutions of end members. Natural silicate garnets prefer to be either non-calcic or calcic [16], and therefore most frequently form a group called pyralspites in which end members all have $\mathrm{Al}^{3+}$ in $\mathrm{Y}$ position, and a group of ugrandites in which end members all have $\mathrm{Ca}^{2+}$ in $X$ position, respectively. End members of the pyralspite group are pyrope $\left(X=\mathrm{Mg}^{2+}\right)$, almandine $\left(\mathrm{X}=\mathrm{Fe}^{2+}\right)$ and spessartine $\left(\mathrm{X}=\mathrm{Mn}^{2+}\right)$, and of the ugrandite group are grossular $\left(\mathrm{Y}=\mathrm{Al}^{3+}\right)$, andradite $\left(\mathrm{Y}=\mathrm{Fe}^{3+}\right)$ and uvarovite $\left(\mathrm{Y}=\mathrm{Cr}^{3+}\right)[17,18]$. Cation exchange and chemical composition of garnets not only dependent on the composition of the source rocks, but also on the temperature and pressure of the formation environment [15]. They are commonly found in different metamorphic rocks and rarely as primary minerals in igneous rocks. Due to the close connection to formation conditions, garnets are a useful indicator of metamorphic facies [19].

Vibrational spectroscopy, including Raman spectroscopy, is useful for distinguishing between different solid solutions as the spectra change as a function of the garnet composition [18]. Although Raman spectra of garnets show similar frequencies of Raman bands for each end member of individual solid solution series (i.e., ugrandites and pyralspites), we can easily distinguish between the spectra of solid solutions due to different cation arrangement [20-23]. The most significant difference in the Raman spectra between the ugrandite serie and pyralspite serie lies in the fact that the relatively strong Raman bands occur at $\sim 360-370 \mathrm{~cm}^{-1}, \sim 513-540 \mathrm{~cm}^{-1}$ and $\sim 870-885 \mathrm{~cm}^{-1}$ for ugrandites and $\sim 342-368 \mathrm{~cm}^{-1}, \sim 555-560 \mathrm{~cm}^{-1}$ and $\sim 905-920$ for pyralspites [20]. Raman bands of garnets are assigned to vibrational modes of Si-O stretching $\left(v_{1}\right.$ and $\left.v_{3}\right)$, Si-O bending $\left(v_{2}\right.$ and $\left.v_{4}\right)$, rotation and translation modes of $\mathrm{SiO}_{4}$ tetrahedron, and the translation mode of the $\mathrm{X}^{2+}$ cation in dodecahedron sites of the garnet crystal lattice [18]. Raman shifts for all members within either of the garnet series are mainly attributed to the atomic mass, atomic structure, ionic radius and polarisations of cations in the $\mathrm{X}$ polyhedra for pyralspites and in the $\mathrm{Y}$ octahedra for the ugrandites, which affect the volume of crystal unit-cell of garnet and force constants of bonds [20,24]. The silicate garnet system pyrope-almandine-spessartine-grossular-andradite-uvarovite shows extensive homovalent substitutional solid solution over two structural sites and complete compositional variation between pyralspite species and ugrandite species has been documented [25]. Thus, the shift of a Raman band due to a chemical substitution is a useful indicator of chemical composition and instead of observing Raman vibrations of these specific elements, one can conveniently observe the shifting of the numerous types of Si-O vibrations within or between the tetrahedral sites [21-23]. For instance, Raman mode frequencies of garnets along the almandine-pyrope solid solution series show the vibrational spectra change with the composition, where the $\mathrm{Si}-\mathrm{O}$ stretching, $\mathrm{Si}-\mathrm{O}$ bending, and the rotation of the $\mathrm{SiO}_{4}$

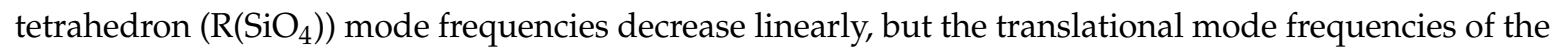
$\mathrm{SiO}_{4}$ tetrahedron $\left(\mathrm{T}\left(\mathrm{SiO}_{4}\right)\right)$ increase with the almandine content [26].

Inclusions are yet another useful tool in interpreting the geological environment in which garnets are formed, although this study area is still under development [27]. Inclusions are either minerals, melts or fluids that can be trapped or formed in various phases of mineral formation [28]. Minerals can be residual reactants or products of the chemical reaction that are responsible for the host formation or 
phases that were not involved in these reactions [29]. Fluid and melt inclusions provide information about material transfers in the Earth system [27]. Melt, fluid or gas phases could also be observed in minerals, which can be trapped or preserved during (re-)crystallisation and are mostly associated with the material transfer in the Earth system, from shallow mineralization to re-fertilization of the mantle by subduction [27].

The characteristics of inclusions can be identified by Raman microspectroscopy. In garnets, solid inclusions are mostly found in almandines, pyrope-almandines and pyropes, although various inclusions or textures may be observed in other types of garnets as presented in Table 1, depending on the environment of formation and origin $[30,31]$.

Table 1. Commonly recognized solid inclusions in garnets [30,31].

\begin{tabular}{|c|c|c|c|}
\hline Group & Composition o & an End Member & Inclusions \\
\hline \multirow{4}{*}{ Pyralspite } & Pyrope & $\mathrm{Mg}_{3} \mathrm{Al}_{2}\left(\mathrm{SiO}_{4}\right)_{3}$ & \multirow{4}{*}{$\begin{array}{c}\text { Apatite, ilmenite, rutile, undetermined fibrous } \\
\text { minerals } \\
\text { Zircon, monazite, apatite, rutile, mica, quartz, } \\
\text { often very pure } \\
\begin{array}{c}\text { Zircon, rutile, mica, hornblende, apatite, spinel, } \\
\text { quartz }\end{array} \\
\text { Rarely present, growth lines - dark wavy } \\
\text { feathers }\end{array}$} \\
\hline & Pyrope-almandine & $(\mathrm{Fe}, \mathrm{Mg})_{3} \mathrm{Al}_{2}\left(\mathrm{SiO}_{4}\right)_{3}$ & \\
\hline & Almandine & $\mathrm{Fe}_{3} \mathrm{Al}_{2}\left(\mathrm{SiO}_{4}\right)_{3}$ & \\
\hline & Spessartine & $\mathrm{Mn}_{3} \mathrm{Al}_{2}\left(\mathrm{SiO}_{4}\right)_{3}$ & \\
\hline \multirow{3}{*}{ Ugrandite } & Andradite & $\mathrm{Ca}_{3} \mathrm{Fe}_{2}\left(\mathrm{SiO}_{4}\right)_{3}$ & \multirow{3}{*}{$\begin{array}{c}\text { Chryzotile } \\
\text { Mostly no inclusions are found } \\
\text { Tsavorite }- \text { zircon, fibrous minerals } \\
\text { Hessonite - zircon, diopside, treacle and heat } \\
\text { wave textures } \\
\text { Not determined }\end{array}$} \\
\hline & Grossular & $\mathrm{Ca}_{3} \mathrm{Al}_{2}\left(\mathrm{SiO}_{4}\right)_{3}$ & \\
\hline & Uvarovite & $\mathrm{Ca}_{3} \mathrm{Cr}_{2}\left(\mathrm{SiO}_{4}\right)_{3}$ & \\
\hline
\end{tabular}

By determining the chemical composition and, in rare cases, even the mineral inclusions of Merovingian Kingdom (mid-5th-7th century AD); gemstones from France, Belgium and South Germany; and five different types of garnets and their probable geographical-geological origin have been possible to be identified to date (e.g., [2-9]). Two types of almandine, group of garnets with the intermediate composition of pyrope-almandine (also in terms of gemmology—rhodolite or pyraldine, e.g., [5]) and two types of pyrope were determined. Differences in the garnet composition are shown in Table 2.

Table 2. Determined groups of garnets from Late Antique-Early Middle age jewellery, according to the definition of Calligaro et al. (2002) [4] and Gilg et al. (2010) [8], based on the chemical composition of garnets.

\begin{tabular}{ccccccc}
\hline Calligaro et al. [4] & Type I & Type II & - & Type III & Type IV & Type V \\
\hline Gilg et al. [8] & Group B & Group A & Group C [10] & Group X & Group D & Group E \\
\hline $\begin{array}{c}\text { Chemical } \\
\text { Composition of } \\
\text { Garnets }\end{array}$ & $\begin{array}{c}\text { Almandines } \\
\text { poor in Mg, } \\
\text { Ca, Mn, also } \\
\text { Cr and } \mathrm{Y}\end{array}$ & $\begin{array}{c}\text { Almandines } \\
\text { rich in } \mathrm{Mg}, \\
\mathrm{Mn} \text {, also } \mathrm{Cr} \\
\text { and } \mathrm{Y}\end{array}$ & $\begin{array}{c}\text { Almandines } \\
\text { rich in Ca and } \\
\mathrm{Mg}\end{array}$ & $\begin{array}{c}\text { Pyrope- } \\
\text { almandines } \\
\text { (rhodolite) }\end{array}$ & $\begin{array}{c}\text { Pyropes } \\
\text { poor in Cr }\end{array}$ & $\begin{array}{c}\text { Pyropes } \\
\text { rich in Cr }\end{array}$ \\
\hline
\end{tabular}

Almandine (Type I and II) garnets supposedly originate from India, with several possible deposits in Rajasthan, Andhra Pradesh and Odisha, whereas rhodolites (Type III) originate from Sri Lanka. Pyropes (Type V) originate from the Czech Republic, but also Portuguese and/or East African pyropes (Type IV) can be found [5-7]. Another variety of almandine garnet with high Ca content (Group C) was found mainly in Scandinavian jewellery $[8,10]$. Depending on the time of the occurrence, rhodolites and Type II almandines were common until the 5th century AD, while type I almandines prevailed since the 6th century AD. In the 7th century AD, significant changes in trading routes occurred on the East, which contributed to the use of Bohemian pyropes (Type V garnets) [8]. 
Optical microscopy and Raman spectroscopy used in inclusion analysis show that mostly apatite, monazite, zircon, uraninite, xenomorphic Fe-chlorite, and rarely rutile, were present in Type I almandines. On the other hand, for type II almandines, xenomorphic quartz crystals, ilmenite, zircon, uraninite, monazite, rutile needles and sillimanite were identified [4,8,31,32]. The latter might indicate the formation in high metamorphic rocks [31,32]. Concerning the geological origin of garnets and their deposits, they are all vastly characterised by various metamorphic rocks of different ages (Precambrian to younger). The Indian deposits are geologically characterised by various rocks of amphibolite to granulite facies (e.g., different types of schists, gneiss and amphibolites) formed during mediumto high-grade metamorphism, which can provide almandines and pyropes of various chemical compositions [33,34]. The island of Sri Lanka is formed of various Precambrian metamorphic rocks (e.g., granulites, gneiss, schists, and quartzite), while intact garnet crystals can be often found in alluvial deposits originating from these rocks [35]. The geological variety of Sri Lanka also greatly contributed to the chemical diversity of almandine-pyrope garnets found on the jewellery. Deposits of pyropes in Bohemia are mainly found in alluvial plains south of the Bohemian massive, although the formation of minerals took place in garnet peridotites [36]; while in Portugal, garnets could be excavated from Palaeozoic gneisses, gabbro or peridotites in the vicinity of Lisbon, where pyropes can still be found [37]. The East African deposits are rich in many gemstones, including spessartines, pyropes and rhodolites; due to the high complexity of the rocks found in the eastern area, many of the deposits remain strongly active [38].

The archaeological site at Lajh in Kranj is one of the most important archaeological cemeteries in Slovenia (Figure 1) dating back to the Late Antiquity (5th to 6th century AD). More than 700 graves have been excavated so far [39]; some of them are rich in metallic artefacts. These small finds are related mainly to the Romans and Germanic tribes of the Lombards and Eastern Goths [40,41]. Ornamented metal jewellery found in the cemetery is especially characteristic of Germanic females. Among other finds, variously fashioned gilded silver and bronze brooches were found, which were decorated with gemstones in the cloisonné technique or more rarely, with a coloured glass [39]. A special type of brooches from this site are S-shaped fibulae, which were mostly found among Romans, Lombardic and other Germanic tribes between the 5th to 7th century AD [42,43].

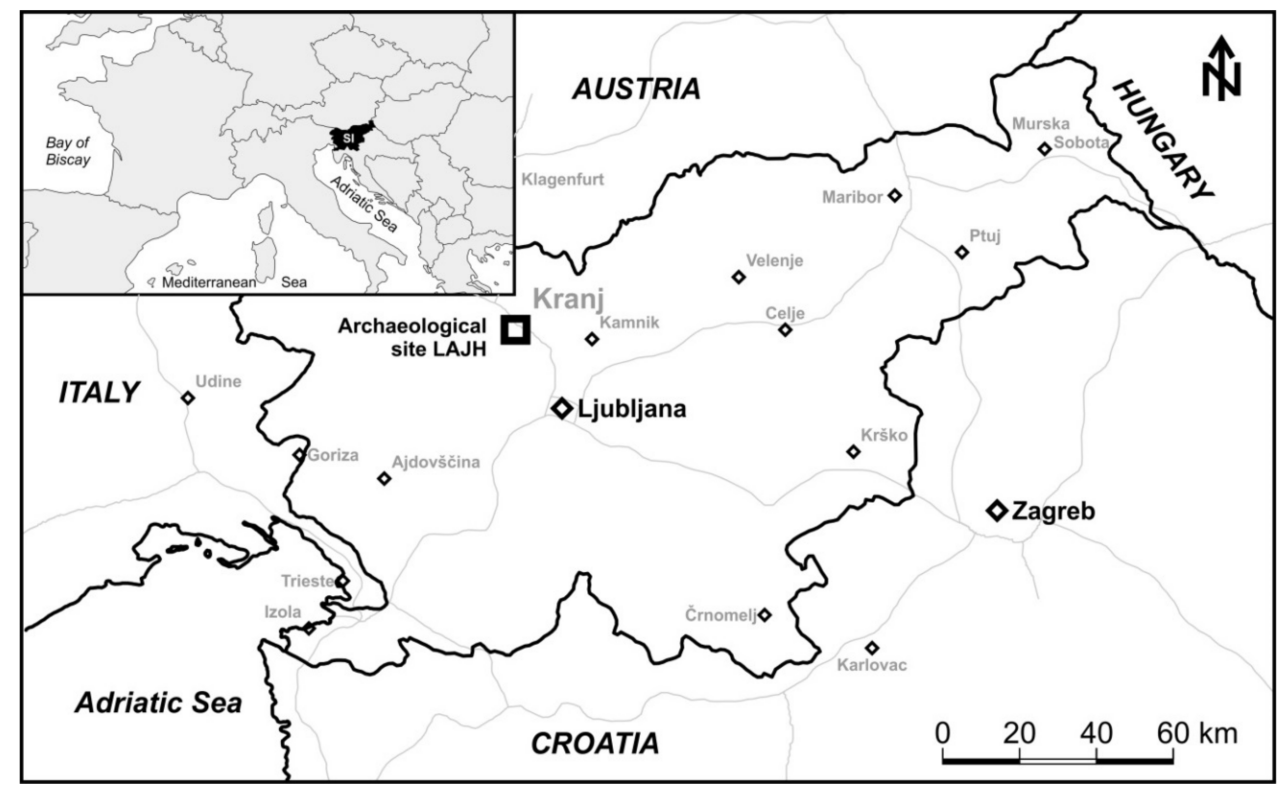

Figure 1. Archaeological site Lajh in city of Kranj in Slovenia.

Several pieces of jewellery and belt buckles from this area have been investigated in earlier works of Kramar et al. (2011) [44], Šmit et al. (2014) [45] and Nemeček et al. (2016) [46] using various analytical techniques (XRF spectroscopy, Raman spectroscopy, PIXE/PIGE). On the studied artefacts, 
Type I almandines dominated, with several examples of Type II almandines and a few rhodolites (Type III). One of three garnet types appears either alone or as a combination of two types on an individual piece of jewellery. All three types of garnets are rarely found together [40]. The investigated garnets of Type I and II correspond to Indian deposits, while Type III rhodolites correspond to the deposits of Sri Lanka, as recognised in previous works [2-8]. Whether the different types of garnets were used intentionally on jewellery is still unknown [45].

The aim of this study was to investigate garnets of Late Antique jewellery (mid- $6^{\text {th }}$ century AD) from Slovenian archaeological site Lajh (Kranj) by means of Raman microspectroscopy in order to determine the type of garnets and inclusions present, as well as to discuss their potential provenance. The data were supported by X-ray fluorescence (XRF) spectroscopy.

\section{Materials and Methods}

\subsection{Artefacts}

A total of 19 garnets from six S-fibulae were analysed in this study, as shown in Figure 2. Fibulae were excavated in 2007 during the archaeological excavation of the Lajh cemetery in Kranj (Slovenia). Fibulae are dated to the mid-6th century AD, according to their specific type Schwechat-Pallersdorf (NA246, NA247, NA843, NA806) [42]. Milavec (2007) [42] described fibulae similar to NA892 as Schwechat-Pallersdorf type alike, which is supposedly a South German derivate of this type. The type of S-fibulae NA401 has not yet been determined. Garnets of the fibulae were polished to approximately 3-mm-thick inlays and attached in metal cell work in the cloisonne technique. Apart from the fibulae NA806 with five, all other fibulae were inlaid with three garnets (on fibula NA892 one of the three garnets is missing). Each garnet was numbered and abbreviated with the letter G (e.g., NA246 G1).
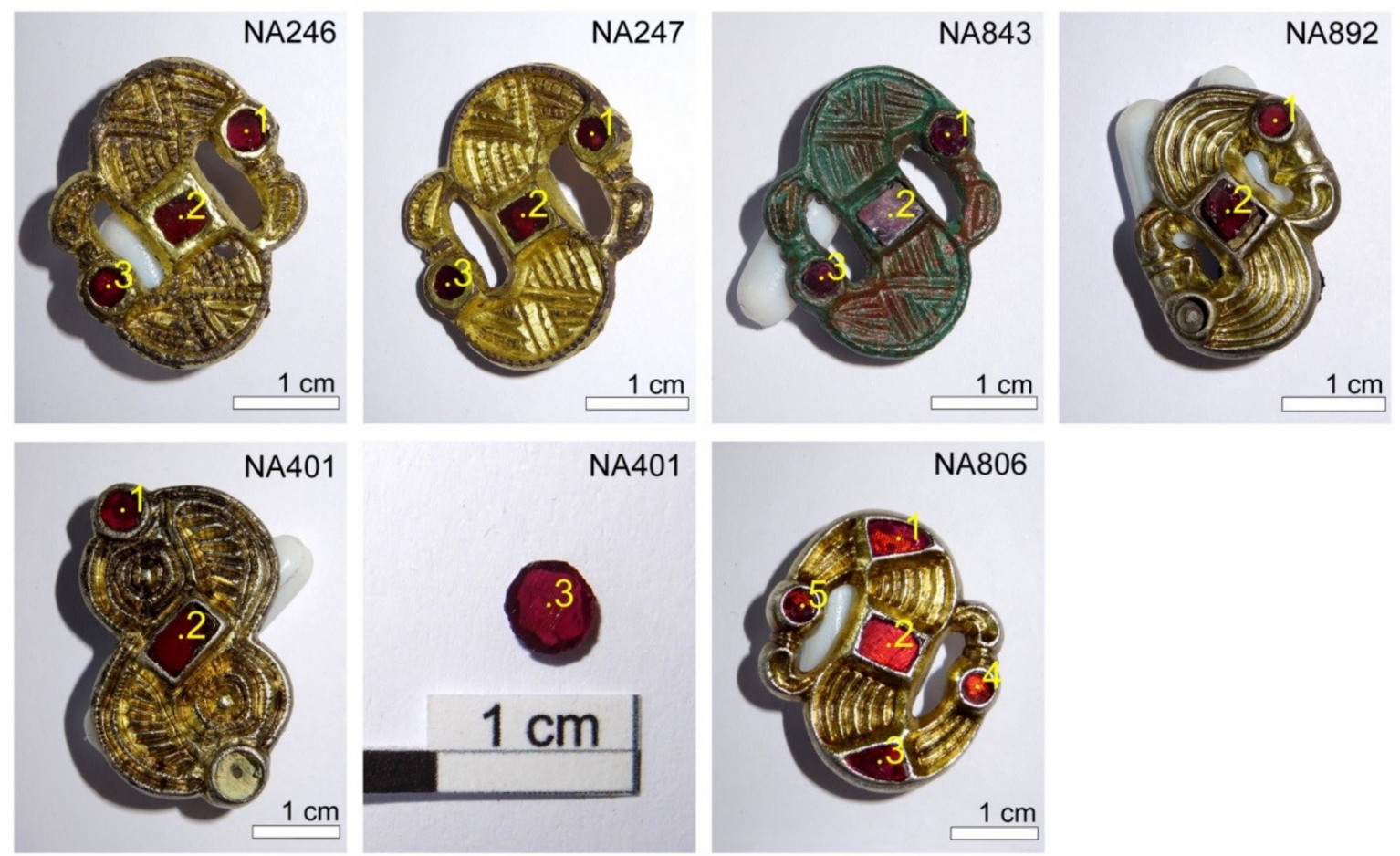

Figure 2. Investigated S-fibulae from the archaeological site at Lajh (Kranj, Slovenia) with labelled garnets.

\subsection{Study of Garnets.}

The Raman spectra of the garnets were obtained using a LabRAM HR800 spectrometer equipped with a high-stability BX 40 optical microscope (Horiba Jobin-Yvon, Villeneuve d'Ascq, France). 
The Raman spectrometer had a grating with 600 grooves per $\mathrm{mm}$ and an air-cooled CCD detector. Measurements were performed in the LabSpec acquisition software program (software version 5.25.15, Horiba Jobin-Yvon, Villeneuve d'Ascq, France) using a $785 \mathrm{~nm}$ laser excitation line with an output power of $31.4 \mathrm{~mW}$ and an Olympus LMPLFL N 50x/0.50 objective, at a spectral resolution of about $1 \mathrm{~cm}^{-1}$. On each garnet, at least three measuring points were selected, with the acquisition time of $60 \mathrm{~s}$. Spectra were acquired in the range of $80-2000 \mathrm{~cm}^{-1}$. All spectra were also analysed in LabSpec 5 Raman spectroscopic data processing software. Baseline corrections or normalisation of spectra were not undertaken. The classical method of multivariate statistics (hierarchical cluster analysis) was applied for checking and evaluating the variability in Raman spectra of studied garnets. Cluster analysis is a typical method that aims to identify similarity patterns (clusters) in a data set. The similarity was detected and demonstrated between the features (bands yielded and shifting of bands in Raman spectra) that characterize the garnets. In general, cluster analysis follows several steps: calculation of the similarity distances; in the present study, the squared Euclidean distances were chosen as similarity measure; linking of the objects to clusters using the Ward's linking method; and graphical representation of the clustering by a hierarchical tree diagram. All statistical calculations were performed with the software package STATISTICA (software version 13.3, TIBCO Software Inc., Munich, Germany). The data used for the cluster analysis are averages of three measurements of Raman mode frequencies for each garnet in the fibulae.

Garnets from the S-fibulae were analysed with the handheld energy dispersive X-ray fluorescence spectroscopy (ED-XRF) Niton instrument GOLDD XL3t 900S-He (0.1 mA; $50 \mathrm{kV})$ (ThermoFisher Scientific, Billerica, MA, USA) with a $3 \mathrm{~mm}$ X-ray spot to determine their chemical composition. The analyses were performed using the $\mathrm{Cu} / \mathrm{Zn}$ Mining mode with continuous helium purge for better detection of light elements $(\mathrm{Mg}, \mathrm{Si}, \mathrm{Al}, \mathrm{S}$ and $\mathrm{P})$, which are included in the manufacturer's software. The reference materials $\mathrm{SiO}_{2}$, NIST- $88 \mathrm{~b}$ and NIST-1d were used at the beginning and end of the measurements to calibrate light elements. The pre-calibration with 25 international standards was performed with the same specifications and preferences as the measurements. Calibration curves were generated for all elements of interest ( $\mathrm{Si}, \mathrm{Al}, \mathrm{Fe}, \mathrm{Mg}, \mathrm{Ca}, \mathrm{Mn}$ ). Two measurements were made on each garnet of the fibulae, with an acquisition time of $210 \mathrm{~s}$ for each measurement. The element assignments were defined using the NITON Data Transfer (version NDT_REL_8.0.1 software, Thermo NITON Analyser LLC, Billerica, MA, USA). The peak intensities for the ED-XRF spectra were given as Counts per Second (cps).

\subsection{Study of Inclusions}

Inclusions in garnets were determined by optical microscopy and Raman microspectroscopy. The microscopic examination of the inclusions in garnets was performed with the Olympus BX-60 optical microscope (Olympus, Tokyo, Japan). One garnet (NA401 G3) was no longer attached to the metal of the fibula that enabled to observe the inclusions in transmitted light. The rest of the garnets were observed in reflected light at both parallel and crossed polars. The microphotographs of inclusions were taken with the Olympus SC50 camera and Olympus Stream software.

The Raman spectra of inclusions were obtained with the same Raman microspectrometer and software settings as for garnet analysis, except for adjusting the acquisition time, which varied between 10 and $60 \mathrm{~s}$. The Raman spectra of inclusions were often masked by a strong signal of garnet, except for the minerals with a strong Raman scattering (e.g., rutile, quartz).

\section{Results}

\subsection{Garnets}

Frequencies of bands in Raman spectra and assigned Raman vibration modes are contained in Table 3. 
Table 3. Raman bands $\left(\mathrm{cm}^{-1}\right)$ for the investigated garnets, assigned to site motion and mode of vibration.

\begin{tabular}{|c|c|c|c|c|c|c|c|c|c|c|c|c|c|c|c|c|c|c|c|c|c|}
\hline \multirow{3}{*}{$\begin{array}{l}\text { Assignment } \\
\text { (mode) }\end{array}$} & \multirow{3}{*}{$\begin{array}{c}\text { Site } \\
\text { Motion } \\
{[22]}\end{array}$} & \multirow{3}{*}{ Band } & \multicolumn{19}{|c|}{ S-fibulae } \\
\hline & & & \multicolumn{3}{|c|}{ NA246 } & \multicolumn{3}{|c|}{ NA247 } & \multicolumn{3}{|c|}{ NA401 } & \multicolumn{3}{|c|}{ NA843 } & \multicolumn{5}{|c|}{ NA806 } & \multicolumn{2}{|c|}{ NA892 } \\
\hline & & & G1 & G2 & G3 & G1 & G2 & G3 & G1 & G2 & G3 & G1 & G2 & G3 & G1 & G2 & G3 & G4 & G5 & G1 & G2 \\
\hline $\begin{array}{l}\text { Translation of } \\
\text { X cation }\end{array}$ & $\mathrm{T}\left(\mathrm{X}^{2+}\right)$ & I & 170.0 & 170.2 & 170.0 & 169.6 & 169.6 & 168.9 & 170.5 & 169.6 & 170.3 & 170.5 & 169.7 & 171.0 & 170.3 & 172.5 & 170.1 & 170.0 & 170.8 & 169.5 & 171.0 \\
\hline $\begin{array}{c}\text { Translation of } \\
\mathrm{SiO}_{4} \\
\end{array}$ & $\mathrm{~T}\left(\mathrm{SiO}_{4}\right)$ & II & 214.4 & 214.2 & 213.5 & 215.0 & 215.0 & 215.0 & 214.2 & 215.6 & 214.5 & 213.9 & 215.2 & 214.0 & 214.3 & 213.2 & 215.5 & 214.4 & 213.7 & 215.9 & 214.2 \\
\hline \multirow{4}{*}{$\begin{array}{l}\text { Rotation of } \\
\mathrm{SiO}_{4}\end{array}$} & $\mathrm{R}\left(\mathrm{SiO}_{4}\right)$ & III & 316.2 & 315.7 & 315.8 & 315.9 & 316.0 & 315.6 & 316.4 & 315.9 & 316.1 & 316.5 & 316.6 & 316.6 & 316.3 & 317.1 & 315.9 & 315.9 & 316.6 & 315.7 & 316.3 \\
\hline & $\mathrm{T}\left(\mathrm{SiO}_{4}\right)$ & IV & 330.8 & 330.8 & 331.5 & 330.8 & 330.9 & 330.3 & 332.3 & 331.9 & 333.0 & 332.9 & 331.9 & . & 331.9 & & 330.6 & 330.8 & 333.6 & 330.3 & 333.5 \\
\hline & $\mathrm{R}\left(\mathrm{SiO}_{4}\right)$ & V & 348.0 & 347.8 & 347.4 & 346.8 & 347.0 & 346.1 & 347.7 & 346.7 & 347.6 & 347.7 & 346.9 & 349.4 & 347.7 & 351.0 & 347.0 & 347.7 & 349.6 & 346.5 & 348.0 \\
\hline & $\mathrm{R}\left(\mathrm{SiO}_{4}\right)$ & VI & 373.2 & 373.0 & 373.2 & 373.1 & 372.9 & 372.9 & 373.2 & 373.0 & 373.3 & 374.1 & 373.4 & 373.6 & 373.8 & 372.6 & 373.6 & 372.9 & 372.8 & 373.0 & 373.2 \\
\hline \multirow{6}{*}{ Si-O bending } & $v_{2}$ & VII & 481.0 & 479.7 & 479.7 & 479.7 & 479.5 & 478.9 & 480.3 & 479.8 & 480.1 & 480.4 & 479.7 & 481.2 & 480.1 & 482.0 & 480.2 & 480.6 & 481.0 & 479.6 & 480.4 \\
\hline & $v_{4}$ & VIII & 501.8 & 501.8 & 501.4 & 501.4 & 501.1 & 500.9 & 501.9 & 501.0 & 501.8 & 501.9 & 501.3 & 502.7 & 502.1 & 503.7 & 501.6 & 502.2 & 502.7 & 501.0 & 502.0 \\
\hline & $v_{2}$ & IX & 557.7 & 557.9 & 557.7 & 557.8 & 557.6 & 556.9 & 558.0 & 557.5 & 558.0 & 558.1 & 557.6 & 558.4 & 558.0 & 559.0 & 558.3 & 558.0 & 558.1 & 557.7 & 558.3 \\
\hline & $v_{4}$ & $x$ & 585.4 & 585.6 & 585.3 & 584.7 & 585.2 & 584.5 & 585.8 & 584.5 & 585.6 & 585.7 & 585.2 & 585.9 & 585.8 & 587.0 & 585.2 & 585.1 & 585.8 & 584.9 & 585.9 \\
\hline & $v_{4}$ & XI & 600.2 & 600.4 & 599.7 & 599.3 & 600.2 & 599.0 & 601.1 & 599.8 & 599.6 & 600.6 & 600.0 & 602.0 & 600.9 & 602.6 & 600.3 & 601.5 & 601.7 & 596.0 & 599.0 \\
\hline & $v_{4}$ & XII & 634.8 & 634.8 & 634.1 & 633.8 & 633.5 & 633.1 & 634.8 & 633.7 & 634.7 & 635.1 & 634.0 & 635.6 & 634.4 & 636.9 & 634.2 & 634.5 & 635.7 & 634.0 & 635.3 \\
\hline \multirow{3}{*}{$\begin{array}{c}\text { Si-O } \\
\text { stretching }\end{array}$} & $v_{3}$ & XIII & 866.4 & 865.4 & 866.1 & 866.0 & 865.8 & 866.0 & 865.6 & 865.3 & 865.7 & 866.4 & 866.3 & 864.3 & 865.5 & 864.6 & 866.5 & 864.9 & 862.9 & 865.6 & 866.7 \\
\hline & $v_{1}$ & XIV & 919.3 & 918.8 & 918.8 & 919.2 & 919.2 & 918.5 & 918.9 & 918.4 & 918.8 & 919.1 & 918.7 & 918.3 & 919.2 & 919.0 & 919.2 & 918.3 & 917.4 & 918.4 & 919.5 \\
\hline & $v_{3}$ & $\mathrm{XV}$ & 1044.0 & 1042.6 & 1042.3 & 1043.4 & 1042.6 & 1042.5 & 1043.7 & 1041.3 & 1043.7 & 1043.3 & 1042.7 & 1044.0 & 1043.6 & 1045.3 & 1042.0 & 1042.5 & 1043.0 & 1042.3 & 1043.7 \\
\hline
\end{tabular}


The Raman spectra of investigated garnets agree well with Raman spectra of pyralspites and the dominant end member almandine [20-22,26], and can be grouped into three distinct energy regions: low frequency regions between (169-374 cm-1$)$; medium energy bands (479-637 $\left.\mathrm{cm}^{-1}\right)$; and high energy peaks $\left(862-1046 \mathrm{~cm}^{-1}\right)$ (Figure 3).

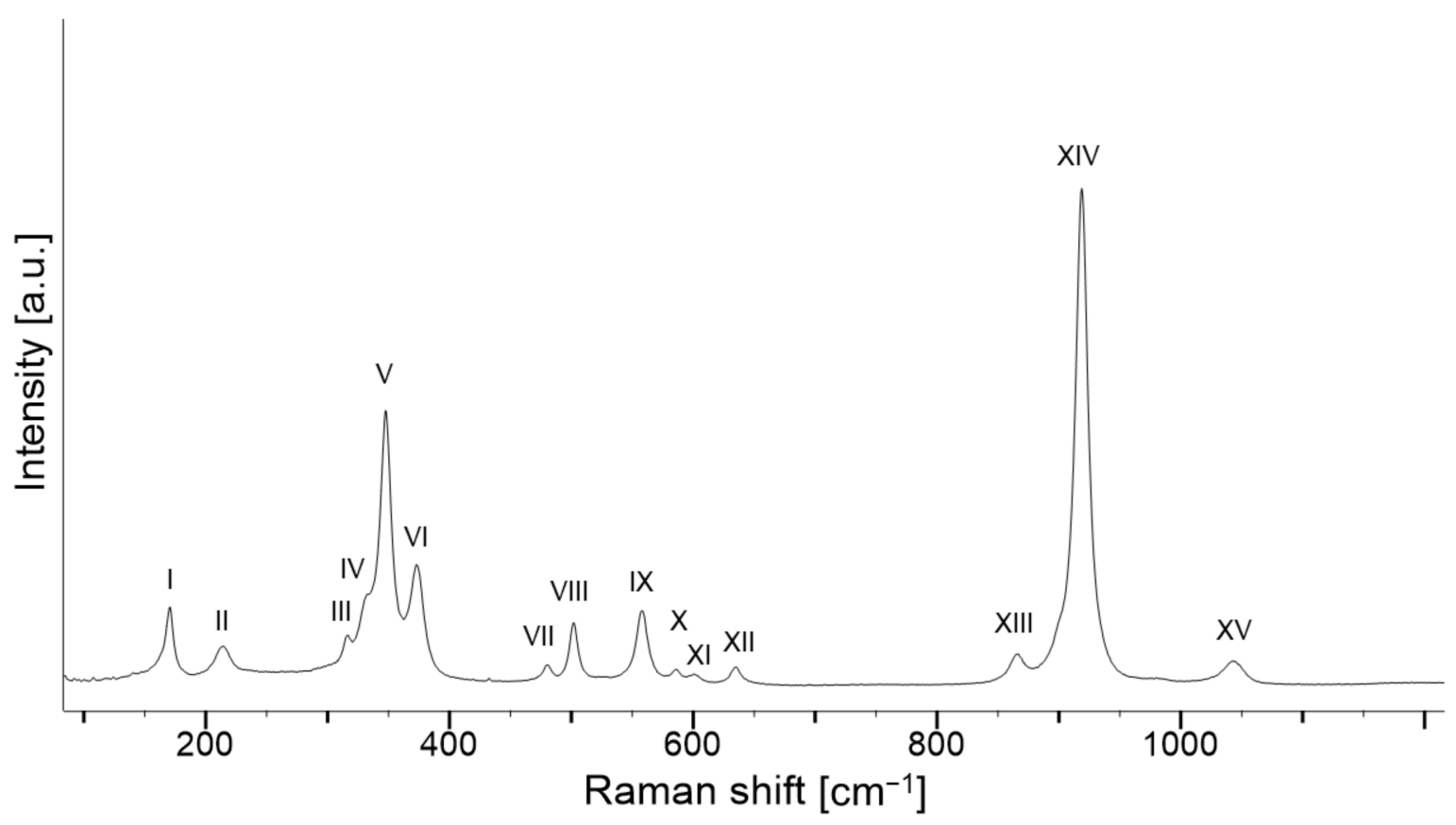

Figure 3. Raman spectrum of almandine garnet (NA247 G1).

Among the expected 25 Raman active modes $\left(3 \mathrm{~A}_{1 \mathrm{~g}}+8 \mathrm{E}_{\mathrm{g}}+14 \mathrm{~T}_{2 \mathrm{~g}}\right)$ of garnet group minerals [20], a total of 15 vibration modes were observed in the Raman spectra obtained that could be grouped into four main regions [22]. The two Raman bands at the range $120-280 \mathrm{~cm}^{-1}$ are assigned to translation modes, i.e., to the translation motion of $\mathrm{Fe}^{2+}$ (band I) [47] and translation motions of $\mathrm{SiO}_{4}($ band II) [22,48]. At the range of $280-450 \mathrm{~cm}^{-1}$, four Raman bands were observed (bands III-VI) dominated by rotation motions of $\mathrm{SiO}_{4}$ [22]. Six Raman bands (bands VII-XII) were located in the range $450-750 \mathrm{~cm}^{-1}$ assigned to $\mathrm{Si}-\mathrm{O}$ bending (symmetric $v_{2}$ or asymmetric $v_{4}$ ), while three Raman bands (bands XIII-XV) yielded at the range 950 to $1100 \mathrm{~cm}^{-1}$ and were assigned to stretching motions of the Si-O band, either symmetric $\left(v_{1}\right)$ or asymmetric stretch $\left(v_{3}\right)$.

As furthermore seen from Figure 4, multivariate analysis based on Raman mode frequencies showed that the 19 garnets are clustered into three major distinct groups. This reflects the results of $X$-ray fluorescence spectroscopy, where in relation to major chemical element contents, three groups of the garnets were recognized (Figure 5). According to ED-XRF spectra, all garnets consisted of $\mathrm{Fe}, \mathrm{Si}$ and $\mathrm{Al}$, confirming almandine composition of the pyralspite solid solution serie. Magnesium, indicating the presence of pyrope component, was also detected, followed by minor Ca (grossular component) and Mn (spessartine component) contents. However, some differences in Fe, $\mathrm{Mg}, \mathrm{Mn}$ and Ca contents were observed for the garnets, which affect the shifting of Raman bands towards higher or lower frequencies. Hence, group II includes seven garnets (NA247 G1-G3, NA401 G2, NA806 G3, NA843 G2 and NA892 G1) and is characterised with the highest Fe contents, whereas Mg, Ca and Mn contents are the lowest among the studied garnets. The lowest values of most of the Raman mode frequencies were observed for this group. On the other hand, group III consisted of three garnets (NA843 G3, NA806 G2 and G5) and is characterised with the highest Mg content as well as Ca and Mn contents and shifting of certain vibrational modes to higher frequencies (e.g., $\mathrm{Si}-\mathrm{O}$ stretching $v_{3}, \mathrm{Si}-\mathrm{O}$ bending $v_{2}$ and $v_{4}$, and rotation of $\mathrm{SiO}_{4}$ modes). However, the majority of analysed garnets belong to 
Group I, which contains nine garnets (NA246 G1-G3, NA401 G1 and G2, NA806 G1 and G4, NA843 G1 and NA892 G2) and is the middle range between Groups II and III.

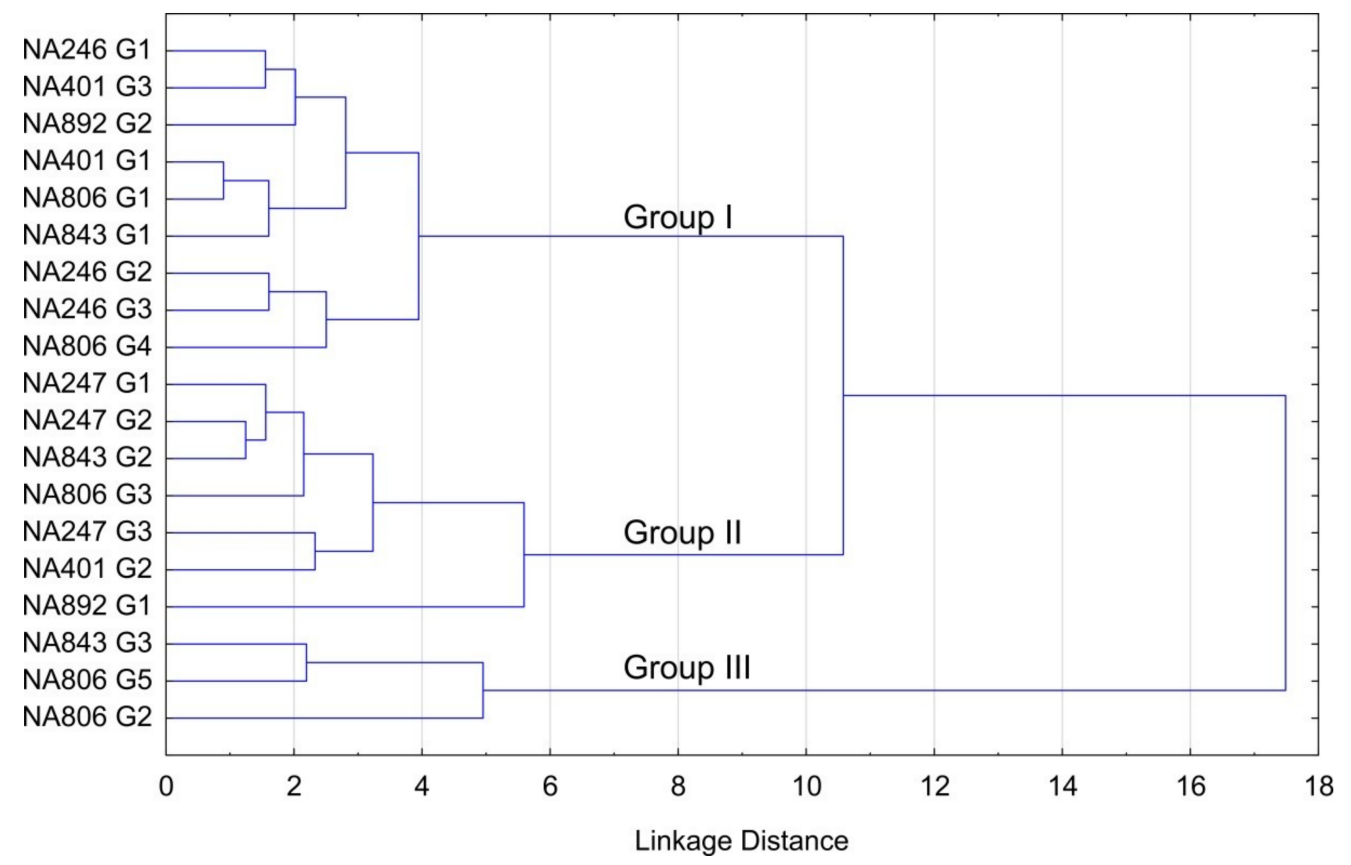

Figure 4. Three diagrams for 19 garnets of the S-fibulae based on Ward's method and squared Euclidean distance using Raman mode frequencies.
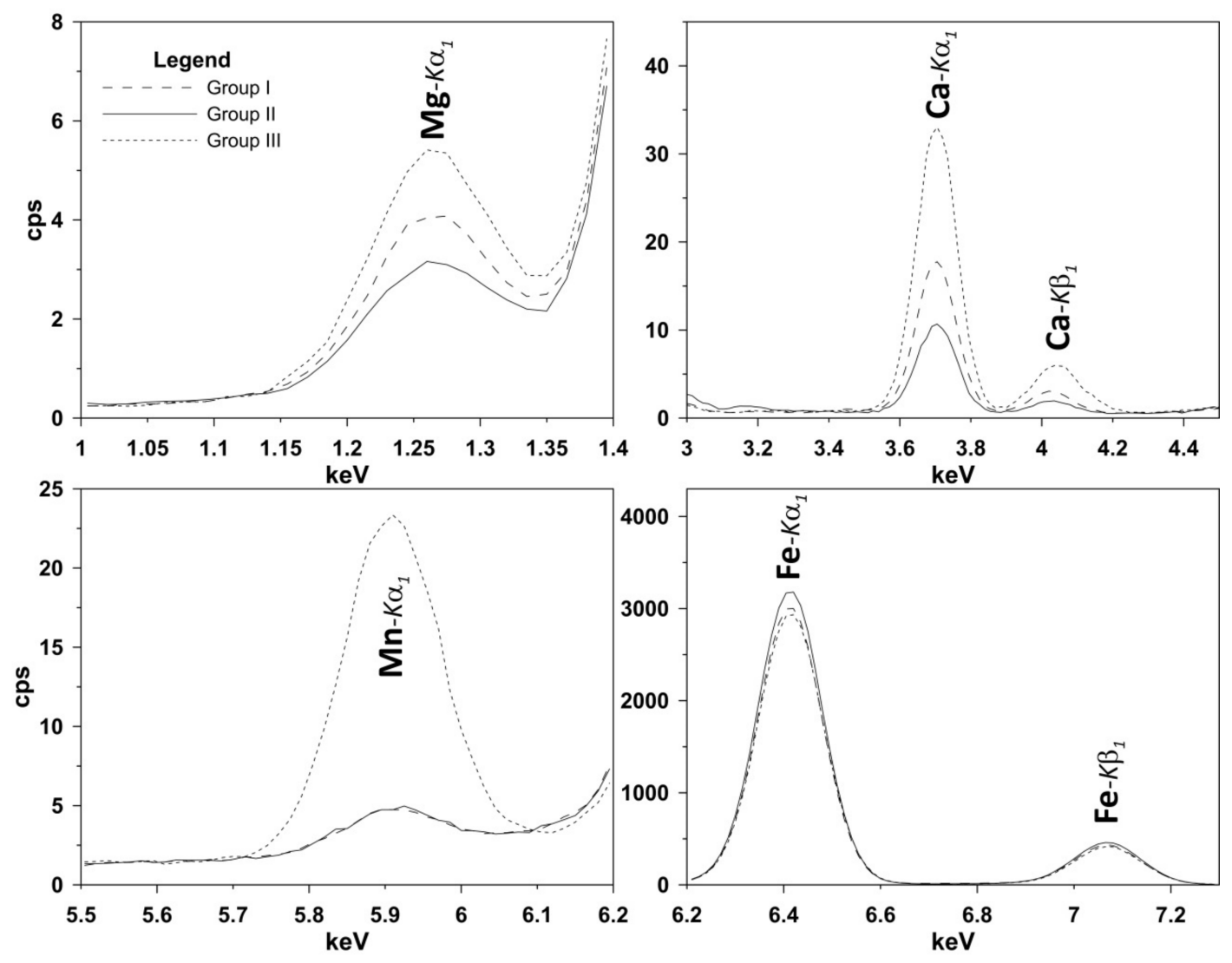

Figure 5. Average intensity ED-XRF spectrum of three-garnet groups. Marked are the $\mathrm{K}_{\alpha 1} / \mathrm{K}_{\beta 1}$ peak of $\mathrm{Mg}, \mathrm{Ca}, \mathrm{Mn}$ and Fe. 
The comparison of Raman spectra of representative members of each group is shown in Figure 6, in which NA247 G3 is assigned to Group I, NA246 G2 to Group II and NA806 G2 to Group III.

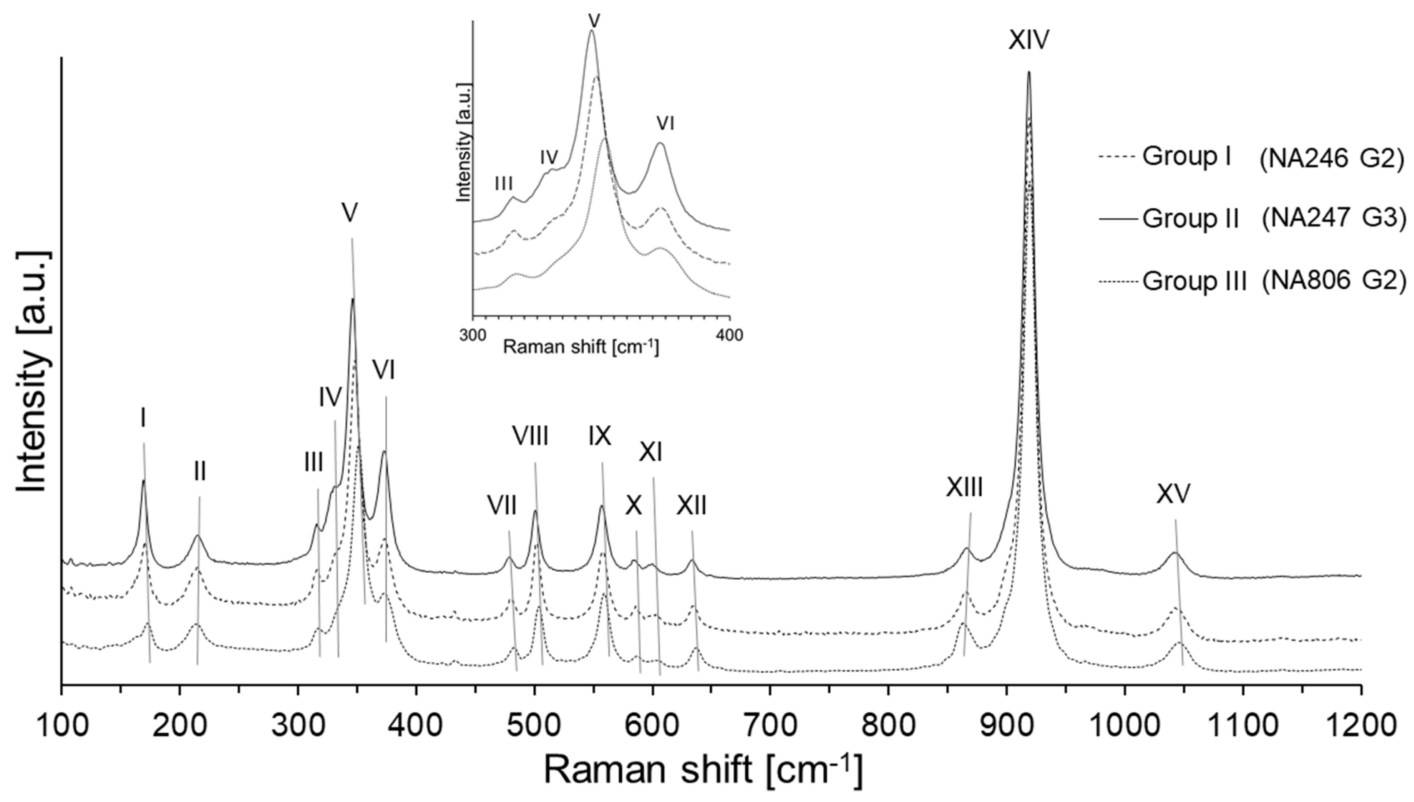

Figure 6. Raman spectra of almandine garnets, representative for each group.

The majority of mode frequencies decrease linearly with the almandine contents (i.e., decrease with ionic radii $\mathrm{Mg}^{2+}{ }_{(0.89)}>\mathrm{Fe}^{2}{ }_{(0.92)} \AA$ ) in all four regions of the Raman spectra. As seen from the Figure 6, this is observed as shifting of certain Raman bands to the left for garnets of group III to group II. Namely, most Raman bands of the pyralspite group can show strong overlap, especially in the range of $\mathrm{Si}-\mathrm{O}$ bending and rotation modes $\mathrm{R}\left(\mathrm{SiO}_{4}\right)$ ). For spessartine, shifts to lower frequencies of $\mathrm{Si}-\mathrm{O}$ stretching mode bands at $905-915 \mathrm{~cm}^{-1}$ and $1030-1035 \mathrm{~cm}^{-1}$ are indicative, due to the presence of a slightly larger $\mathrm{Mn}^{2+}$ ion in the octahedral coordination, with respect to the $\mathrm{Fe}^{2+}$ ions in almandine [11,20]. On the contrary, in pyrope, the presence of smaller $\mathrm{Mg}^{2+}$ cation in octahedral coordination [18] affects the shifts of several vibrational modes to higher frequencies, especially $\sim 363 \mathrm{~cm}^{-1}, \sim 510 \mathrm{~cm}^{-1}, \sim 640 \mathrm{~cm}^{-1}$ and $\sim 1055 \mathrm{~cm}^{-1}$ [20,43]. In addition, Raman bands at $\sim 170 \mathrm{~cm}^{-1}$ (band I) and $\sim 330 \mathrm{~cm}^{-1}$ (band VI) showed a tendency to diminish towards pyrope composition as also recognised by Pinet and Smith (1994) [22]. Anyway, some bands, for instance, Raman band at $214 \mathrm{~cm}^{-1}$ (band II) assigned to the translational mode of the $\mathrm{SiO}_{4}$ tetrahedron, showed the opposite trend with increasing the mode frequencies with almandine contents. An inverse correlation with ionic radii $\mathrm{Mg}^{2+}{ }_{(0.89)}<\mathrm{Fe}^{2+}(0.92)<$ $\mathrm{Mn}^{2+}{ }_{(0.96)} \AA$ for this frequency mode was reported also by other authors [22,26].

Figure 7 shows trends in the selected frequency distribution from the four ranges of the Raman spectra assigned to the translation mode of the $\mathrm{X}^{2+}$ cation (band I), rotation of the $\mathrm{SiO}_{4}$ tetrahedron (band V) and vibration modes of Si-O bending ( $v_{4}$-band XII) and Si-O stretching $\left(v_{3}-\right.$ band XV). Raman shifts of vibration modes were attributed to the changes in the end member composition, which was confirmed by XRF spectroscopy (Figure 5). The lowest observed frequency modes in the ranges of $169-170 \mathrm{~cm}^{-1}, 346-347 \mathrm{~cm}^{-1}$ and $633-634 \mathrm{~cm}^{-1}$ are the result of higher Fe contents for the garnets of the Group II. On the other hand, the increase of Mg content affected the shifts of the Raman bands in the ranges of $171-173 \mathrm{~cm}^{-1}, 350-352 \mathrm{~cm}^{-1}$ and $635-637 \mathrm{~cm}^{-1}$ to higher frequencies in three investigated garnets of Group III (NA806 G2 and G5, NA843 G3), respectively (Figure 7a-c). The proposed trend could not be observed completely in the distribution of frequencies $1041-1045 \mathrm{~cm}^{-1}$ (Figure $7 \mathrm{~d}$ ) assigned to $\mathrm{Si}-\mathrm{O}$ stretching $\left(v_{3}\right)$. With the exception of NA247 G2, the frequencies for the garnets of group II were shifted to lower values, whereas for the garnet of group III, NA806 G2, the band for this mode was shifted to higher frequencies, which corresponds to increased $\mathrm{Mg}$ content 
within the group. Rather low frequency was observed for the garnets NA806 G5 and NA892 G1, which could be explained with slightly lower values of $\mathrm{Mg}$ and enhanced contents of $\mathrm{Mn}$ compared to garnet NA806 G2 within group III.

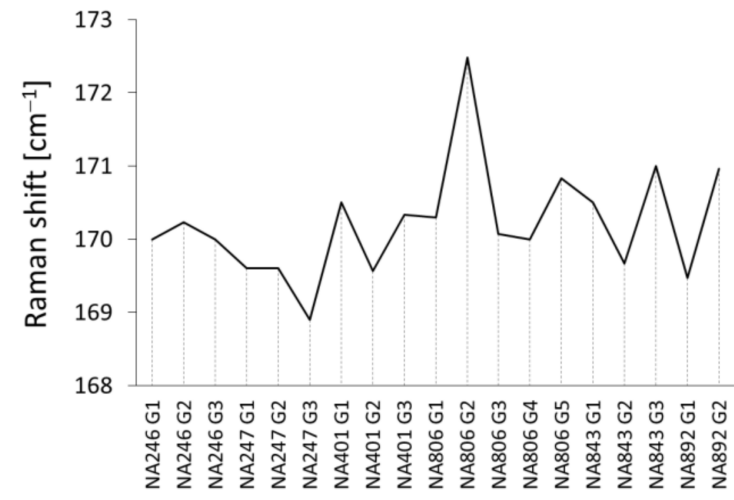

(a)

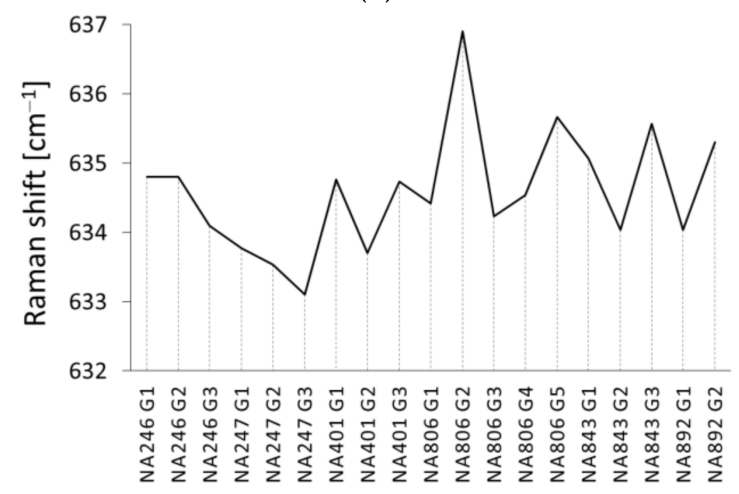

(c)

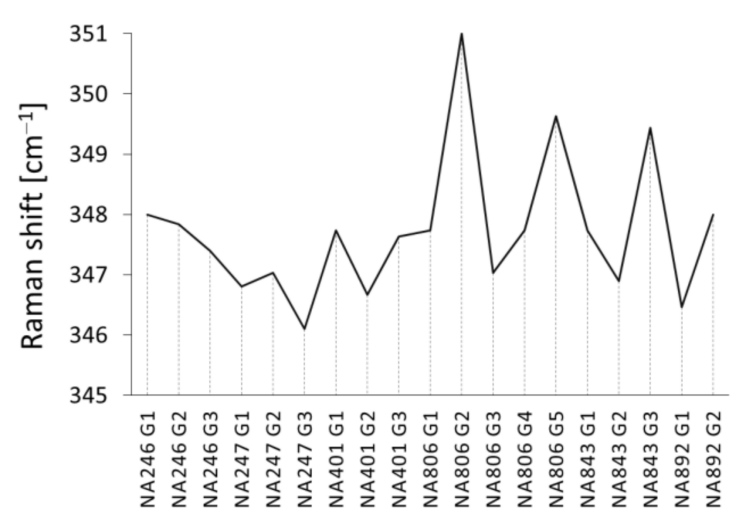

(b)

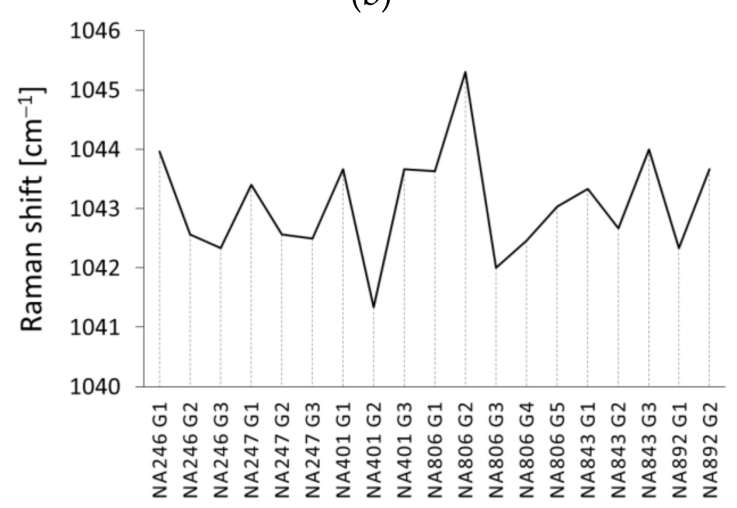

(d)

Figure 7. Selected Raman mode frequencies change (a) Raman shifts for translation mode of the $\mathrm{X}^{2+}$ cation in the range of $169-173 \mathrm{~cm}^{-1}$ (band I); (b) Raman shifts for tetrahedron rotation in the range 346-352 $\mathrm{cm}^{-1}$ (band V); (c) Raman shifts for Si-O bending mode in the range of $633-637 \mathrm{~cm}^{-1}\left(v_{4}\right)$ (band XII); (d) Raman shifts for Si-O stretching mode in the range of $1041-1045 \mathrm{~cm}^{-1}\left(v_{3}\right)$ (band XV).

\subsection{Inclusions}

As observed by optical microscopy, garnets from S-fibulae contained several inclusions that were additionally examined by Raman microspectroscopy. Most of the studied garnets contained apatite, quartz and minerals with radiation and pleochroic halo (e.g., zircon). Some also contained mica (muscovite, phlogopite) and opaque minerals (ilmenite). Rutile was observed only in two garnets, while sillimanite fibres only appeared in one garnet. In two of the garnets, unidentified spherical inclusions were observed, which could be fluid or gas inclusions. The inclusions determined in garnets are listed in Table 4. Figures 8-16 show characteristic microphotographs of mineral inclusions and their associated Raman spectra. 
Table 4. Observed inclusions in garnets from S-fibulae, regarding a type of inclusion, their mineralogy and affiliation to certain garnets.

\begin{tabular}{|c|c|c|}
\hline Type of Inclusion & Mineralogy and Chemical Formula & Artefact and Garnet \\
\hline \multirow{3}{*}{ Transparent crystal } & Quartz $\mathrm{SiO}_{2}$ & NA401 G3, NA806 G2, G4 and G5 \\
\hline & Apatite $\mathrm{Ca}_{5}\left(\mathrm{PO}_{4}\right)_{3}(\mathrm{Cl} / \mathrm{F} / \mathrm{OH})$ & $\begin{array}{l}\text { All garnets of fibulae NA246, } \\
\text { NA247, NA401, NA806 G1 and G4 }\end{array}$ \\
\hline & $\begin{array}{l}\text { Mica (muscovite } \mathrm{KAl}_{2}\left(\mathrm{AlSi}_{3} \mathrm{O}_{10}\right)(\mathrm{OH})_{2} \text { or } \\
\left.\text { phlogopite } \mathrm{KMg}_{3}\left(\mathrm{AlSi}_{3} \mathrm{O}_{10}\right)(\mathrm{OH})_{2}\right)\end{array}$ & NA401 G3, NA806 G2, G4 and G5 \\
\hline $\begin{array}{l}\text { Crystal with } \\
\text { radiation halo, } \\
\text { pleochroic halo or } \\
\text { tension fissures }\end{array}$ & Zircon $\mathrm{Zr}\left(\mathrm{SiO}_{4}\right)$ & $\begin{array}{l}\text { NA246 G2, NA247 G2, NA401 G2, } \\
\text { NA806 G2, } 3 \text { and 5, NA843 G2 }\end{array}$ \\
\hline Transparent fibres & Sillimanite $\mathrm{Al}_{2}\left(\mathrm{SiO}_{4}\right) \mathrm{O}$ & NA806 G2 \\
\hline Opaque clusters & Magnetite $\left(\mathrm{Fe}^{2+}, \mathrm{Fe}^{3+}\right)_{2} \mathrm{O}_{4}$, ilmenite $\mathrm{Fe}^{2+} \mathrm{TiO}_{3}$ & NA247 G1 and 2, NA401 G2 \\
\hline Opaque needles & Rutile $\alpha-\mathrm{TiO}_{2}$ & $\begin{array}{l}\text { NA806 G5, } \\
\text { NA843 G3 }\end{array}$ \\
\hline Brownish plate & $\begin{array}{c}\text { Biotite } \\
\mathrm{K}\left(\mathrm{Fe}^{2+} / \mathrm{Mg}\right)_{2}\left(\mathrm{Al} / \mathrm{Fe}^{3+} / \mathrm{Mg}\right)\left(\left[\mathrm{Si} / \mathrm{Al}^{3} \mathrm{Si}_{2} \mathrm{O}_{10}\right)(\mathrm{OH} / \mathrm{F})_{2}\right. \\
\text { or Xenotime }(\mathrm{Y} / \mathrm{Yb})\left(\mathrm{PO}_{4}\right)\end{array}$ & NA892 G2 \\
\hline Spherical inclusions & unidentified (melt, fluid or gas) & NA843 G1, NA892 G2 \\
\hline
\end{tabular}

Apatite was determined in garnets from fibulae labelled NA246, NA247, NA401, NA806 (G1 and G4) and NA892 (G1). As shown in Figure 8b, strong characteristic Raman bands of apatite yielded at $272 \mathrm{~cm}^{-1}, 432 \mathrm{~cm}^{-1}, 592 \mathrm{~cm}^{-1}, 965 \mathrm{~cm}^{-1}$ and $1083 \mathrm{~cm}^{-1}$ [49]. Apatite mainly occurred as elongated xenomorphic crystals, from 50 to $300 \mu \mathrm{m}$ in size (Figure 8a). However, in garnet G3 from fibula NA401, it occurred as idiomorphic crystals in a size of approximately $300 \mu \mathrm{m}$.

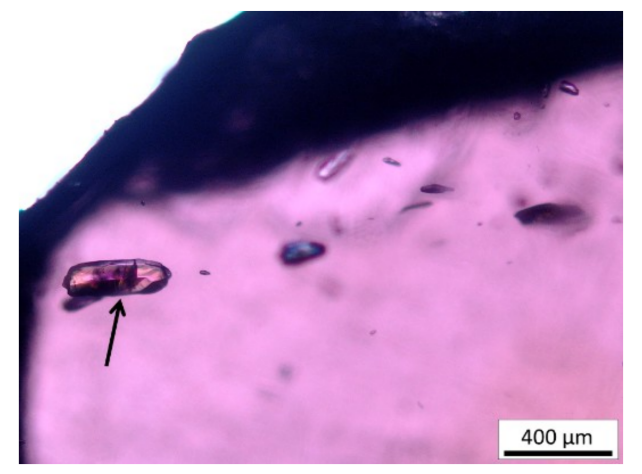

(a)

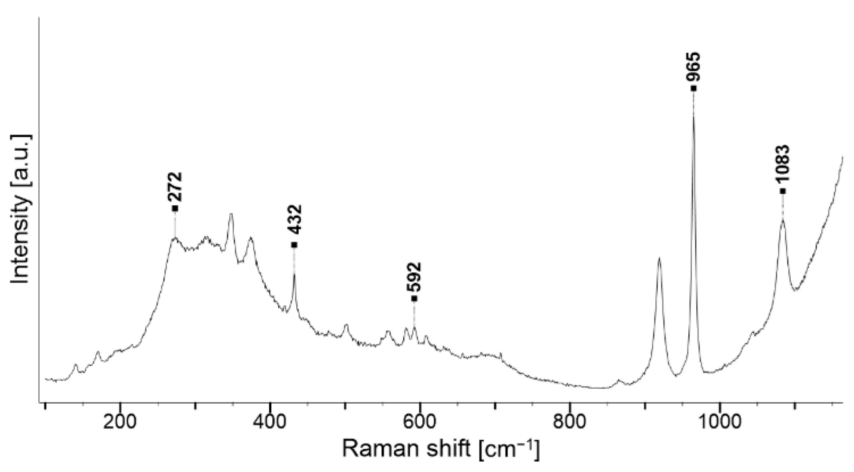

(b)

Figure 8. Inclusions in garnet G3 of fibula NA401. (a) Idiomorphic apatite inclusion. Reflected light, parallel polars; (b) Raman spectrum of apatite in almandine garnet.

Garnet G3 from fibula NA401 also contained several xenomorphic grains of quartz in a size of up to $20 \mu \mathrm{m}$ (Figure 9a). Characteristic Raman bands at 128, 208 and $465 \mathrm{~cm}^{-1}$ confirmed the presence of $\alpha$-quartz, however, some spectra also yielded minor bands at $394 \mathrm{~cm}^{-1}$ [50] (Figure $9 \mathrm{~b}$ ). Quartz inclusions were also identified in other garnets (NA806 G2, G4 and G5).

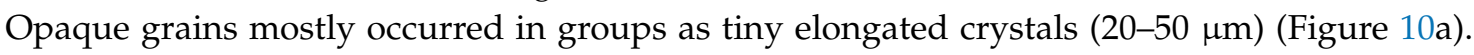
These inclusions were identified in fibulae NA247 (G1 and G2) and NA401 G2. Raman bands indicating the presence of iron oxide minerals were observed in several spectra, e.g., in Figure 10b, where besides quartz (black asterisk), a broad band at $\sim 680 \mathrm{~cm}^{-1}$ is also visible (red asterisk), which could be assigned to ilmenite [50-52]. Namely, ilmenite flakes with quartz inclusions are commonly found in garnets [31]. 


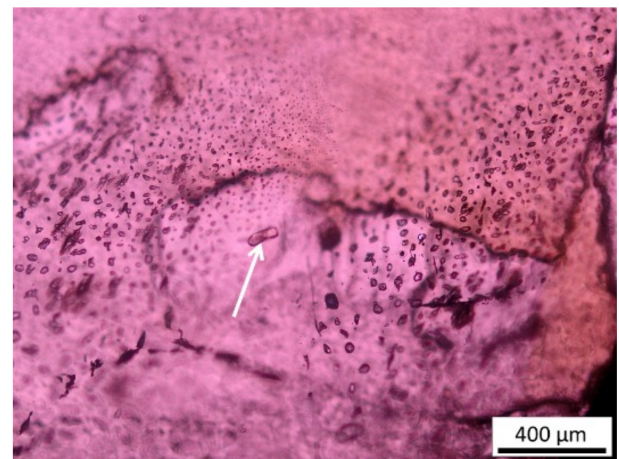

(a)

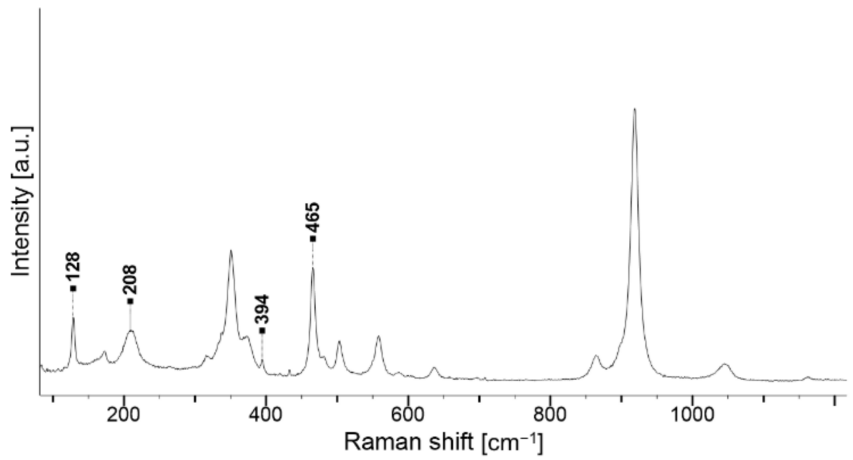

(b)

Figure 9. Inclusions in garnet G3 of fibula NA401. (a) Xenomorphic inclusion of quartz. Transmitted light, parallel polars; (b) Raman spectrum of quartz in almandine garnet.

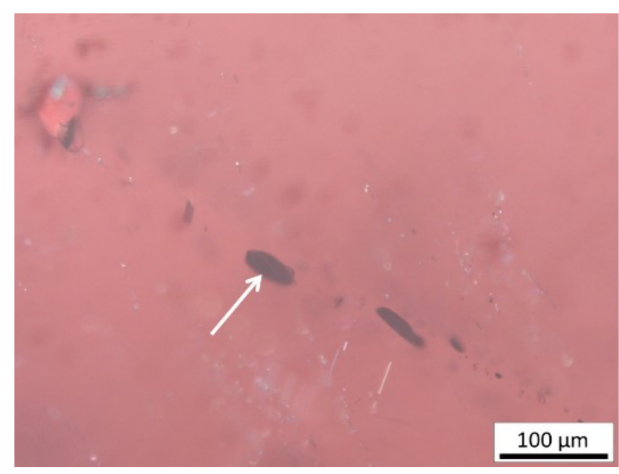

(a)

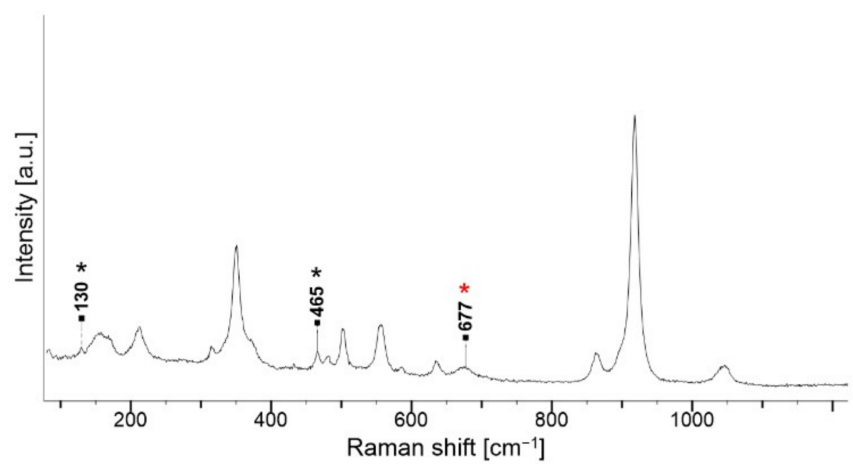

(b)

Figure 10. Inclusions in garnet G1 of fibula NA247 and garnet G2 of fibula NA401. (a) A group of elongated inclusions of Fe oxides (i.e., ilmenite) in NA401 G2. Reflected light, parallel polars; (b) Raman spectrum of quartz with bands at 130, $465 \mathrm{~cm}^{-1}$ (black asterisk) and ilmenite at $\sim 680 \mathrm{~cm}^{-1}$ (red asterisk) in almandine garnet.

Thin intersecting rutile needles were visible in two garnets, NA806 G5 and NA843 G2 (Figure 11a). In the latter, the Raman spectrum of rutile (Figure 11b) was obtained with broad Raman bands at 448 and $609 \mathrm{~cm}^{-1}$ and a weak band at $143 \mathrm{~cm}^{-1}$.

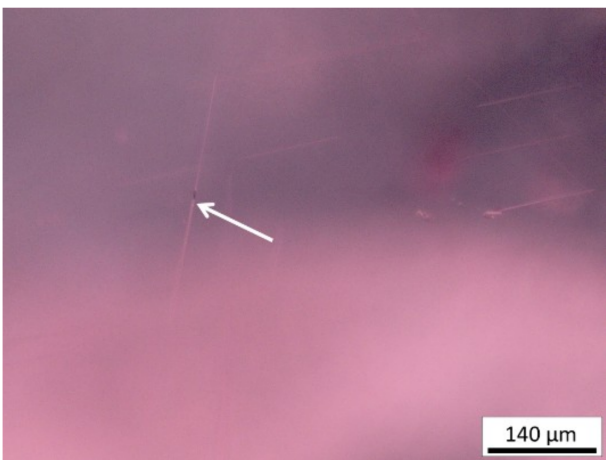

(a)

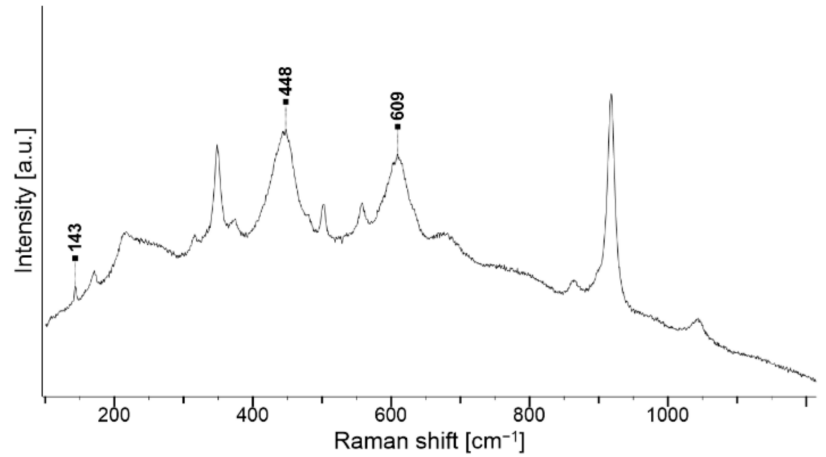

(b)

Figure 11. Inclusions in garnet G3 of fibula NA843. (a) Needles of rutile. Reflected light, parallel polars; (b) Raman spectrum of rutile in almandine garnet.

Anhedral rounded inclusions with pleochroic (brownish) or radiation halo and inclusions damaged with tension fissures are common in most of the investigated garnets (Figure 12a-d). Their size varies 
from 20-200 $\mu \mathrm{m}$. They occurred in fibulae NA246 (G2), NA247 (G2), NA401 (G2), NA806 (G2, G3 and G5) and NA843 (G2). Inclusions with tension fissures are minerals, in which a deformation of the crystal lattice occurs due to changes in the environmental conditions (pressure, temperature) during the growth of the host crystal or in subsequent processes, that influence changes in the structure of the host crystal [53]. Pleochroic or radiation halos are the result of radiation damage within the host crystal structure, caused by the process known as metamictization [18]. This process is characteristic for crystals containing radioactive elements in their crystal structure and can result in radiation damage and crystalline structure changes to an amorphous state, while the outer crystal shape is retained [18]. Such minerals are zircon, monazite, xenotime or apatite, which accommodate thorium or uranium into the crystal structure [54].

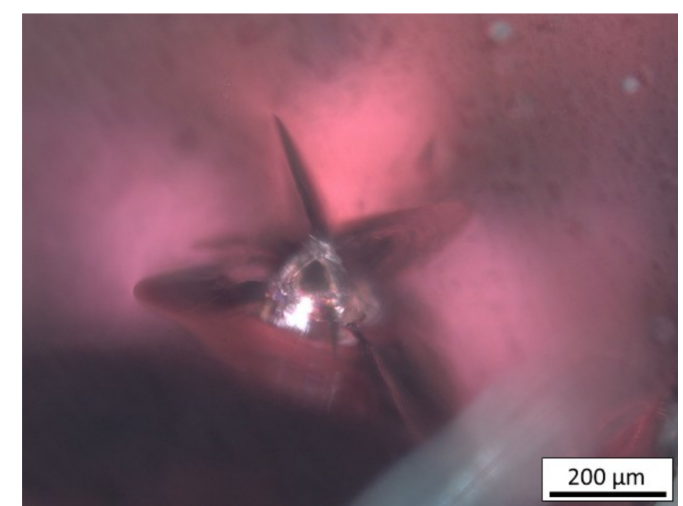

(a)

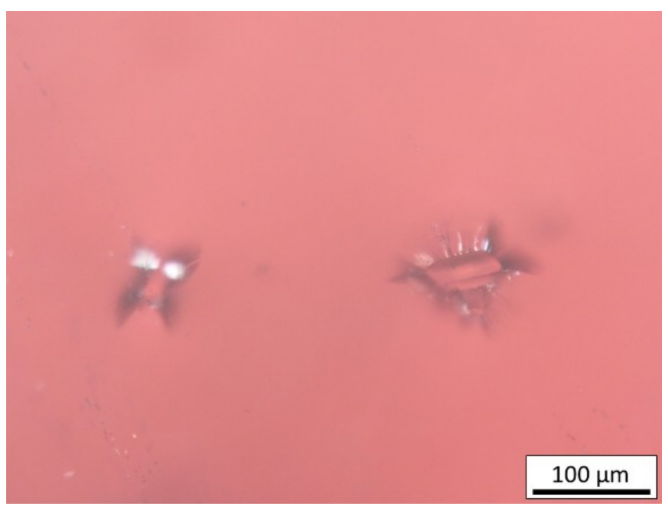

(c)

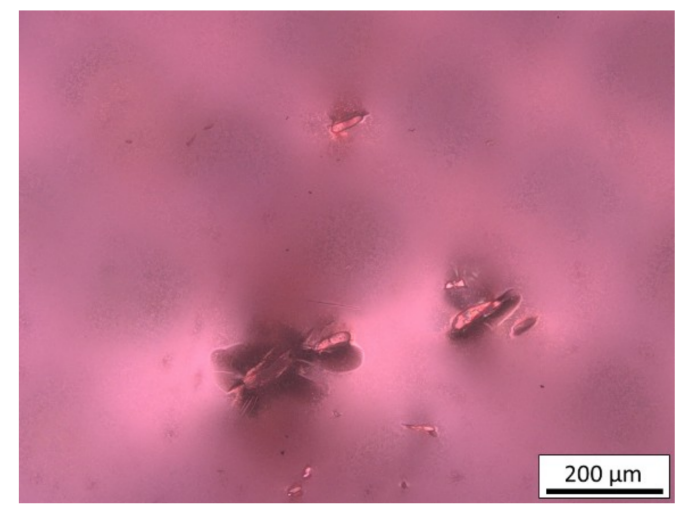

(b)

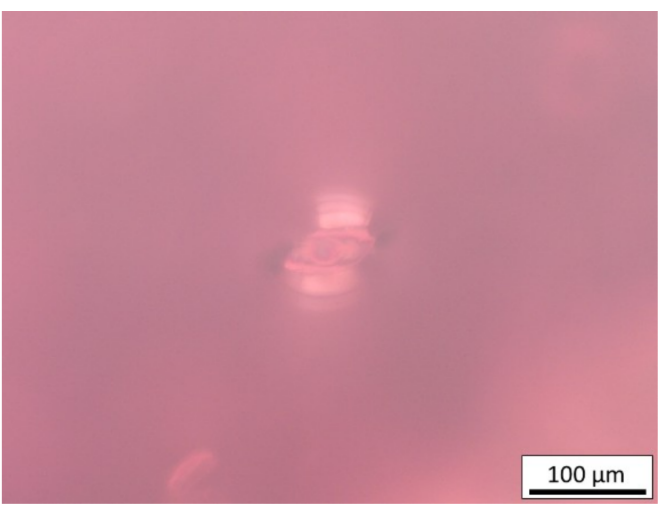

(d)

Figure 12. Inclusions with radiation deformations. Reflected light, parallel polars. (a) Inclusion with a pleochroic halo in garnet G2 of fibula NA843; (b) several inclusions with pleochroic halo in garnet G2 of fibula NA806; (c) small inclusions with pleochroic halo and probably tension fissures in garnet G2 of fibula NA247; (d) light radiation halo around inclusion in garnet G2 of fibula NA246.

Raman spectra of some deformed inclusions showed strong luminescence, which masked most bands (Figure 13). A weak Raman band at $\sim 1014-1017 \mathrm{~cm}^{-1}$ and a stronger band at $\sim 1398 \mathrm{~cm}^{-1}$, often accompanied by a broad band at $1280 \mathrm{~cm}^{-1}$, can be indicative of zircon. Namely, as suggested by some authors (i.e., Kloprogge (2017) [18], Nasdala et al. (2002, 2018) [55,56]), the crystal structure of zircon inclusion may be damaged due to metamictization or pressurization in their hosting minerals resulting in decreasing of intensity and broadening of the strong Raman band characteristic of zircon at $\sim 1008 \mathrm{~cm}^{-1}$. Moreover, an increase in temperature and pressure will cause a shift and lower the intensity of the Raman band to $1014-1022 \mathrm{~cm}^{-1}$ [57]. However, luminescence and presence of strong Raman bands in the range of $1200-1400 \mathrm{~cm}^{-1}$ are related to amorphous $\mathrm{SiO}_{2}$, which appears due to changes in inclusions after heath treatment [57]. 


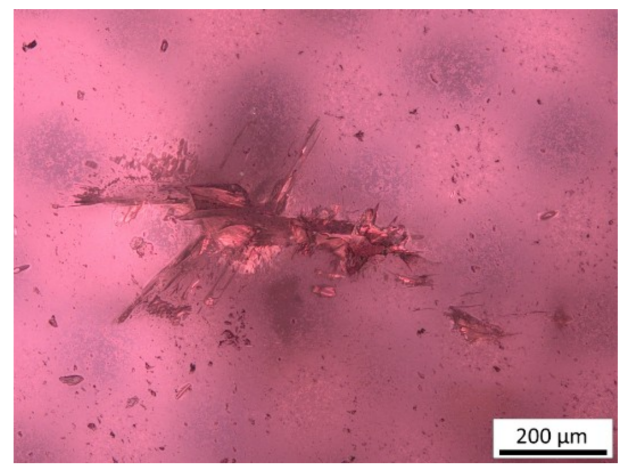

(a)

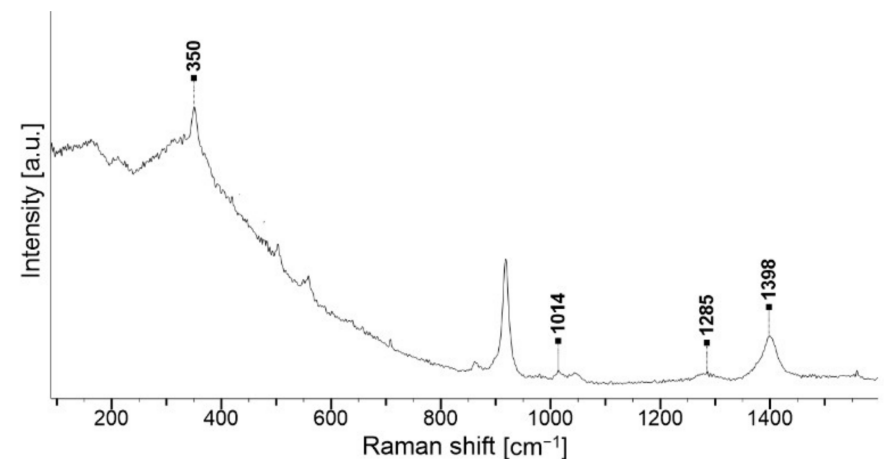

(b)

Figure 13. Inclusion in garnet G2 of fibula NA806. (a) Inclusion deformed by tension fissures. Reflected light, parallel polars; (b) Raman spectrum of inclusion with strong luminescence and Raman bands at $\sim 1014 \mathrm{~cm}^{-1}, \sim 1286 \mathrm{~cm}^{-1}$ and $\sim 1399 \mathrm{~cm}^{-1}$ indicating presence of zircon in almandine garnet.

Raman spectra of particular xenomorphic transparent crystals of 20 to $200 \mathrm{um}$ in size that corresponded to mica were observed in several garnets (NA401 G3, NA806 G2, G4 and G5 (Figure 14). Namely, two types of phyllosilicates were recognised. Raman bands at $\sim 100$ and $\sim 700 \mathrm{~cm}^{-1} \mathrm{are}$ indicative of muscovite type (Figure 14b, below), whereas at $\sim 670-680 \mathrm{~cm}^{-1}$ of phlogopite type (Figure 14b, above) [58]. According to Schönig et al. (2018) [59], bands determined at 190-200 cm can be present for both types of mica, however, a strong band of $\sim 270 \mathrm{~cm}^{-1}$ is characteristic only in muscovite-paragonite type.

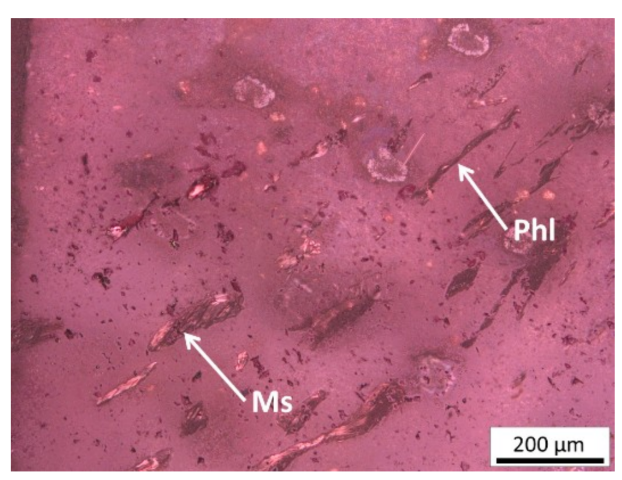

(a)

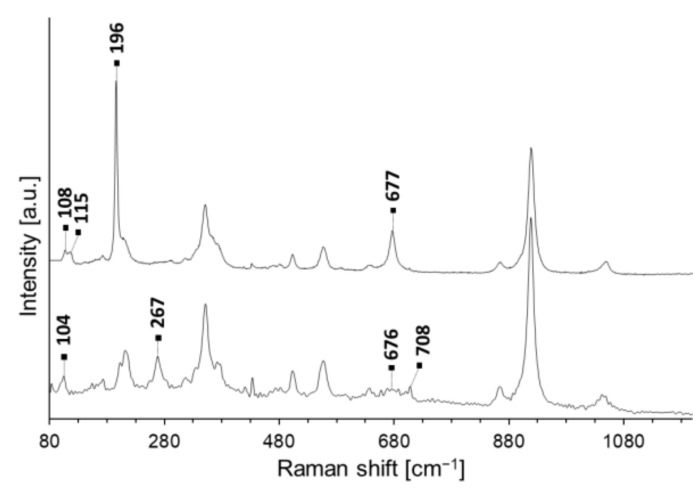

(b)

Figure 14. Xenomorphic grains in garnet G2 of fibula NA806. (a) Xenomorphic inclusions of mica (i.e., muscovite or/and phlogopite). Reflected light, parallel polars; (b) Raman spectrum of muscovite (Ms, spectrum below)) and Raman spectrum of phlogopite (Phl, spectrum above) in almandine garnet.

Among the investigated garnets, only in garnet G5 of fibula NA806 fibre-like inclusions were present, which might be attributed to sillimanite (Figure 15a). Similar curved fibres of sillimanite were also determined in almandines by Calligaro et al. (2002) [4], Schmetzer et al. (2014) [31] and Horváth and Bendó (2011) [32]. Due to strong luminescence, only a Raman band at $235 \mathrm{~cm}^{-1}$ (black asterisk) is present besides common almandine bands $\left(171 \mathrm{~cm}^{-1}, 312 \mathrm{~cm}^{-1}, 349 \mathrm{~cm}^{-1}, 558 \mathrm{~cm}^{-1}\right.$ and $918 \mathrm{~cm}^{-1}$ ) (Figure 15b). For sillimanite, bands at $\sim 235 \mathrm{~cm}^{-1}, 310 \mathrm{~cm}^{-1}, 456 \mathrm{~cm}^{-1}, 870 \mathrm{~cm}^{-1}$ and $965 \mathrm{~cm}^{-1}$ are characteristic $[50,60]$. Raman bands at 235 and $312 \mathrm{~cm}^{-1}$ (for analysed almandine garnets, this band is observed at slightly higher values $315-317 \mathrm{~cm}^{-1}$ ) could indicate the presence of sillimanite. 


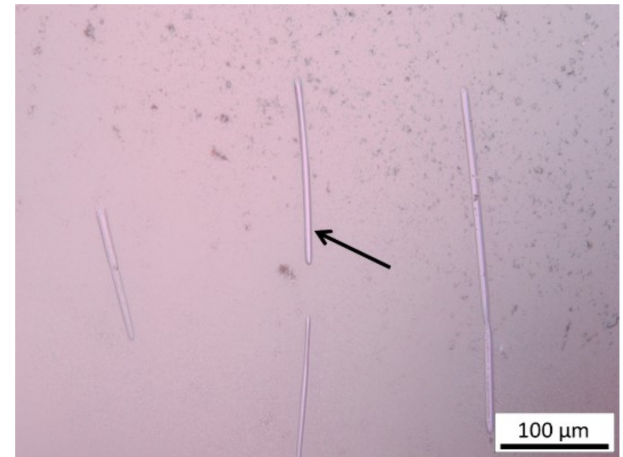

(a)

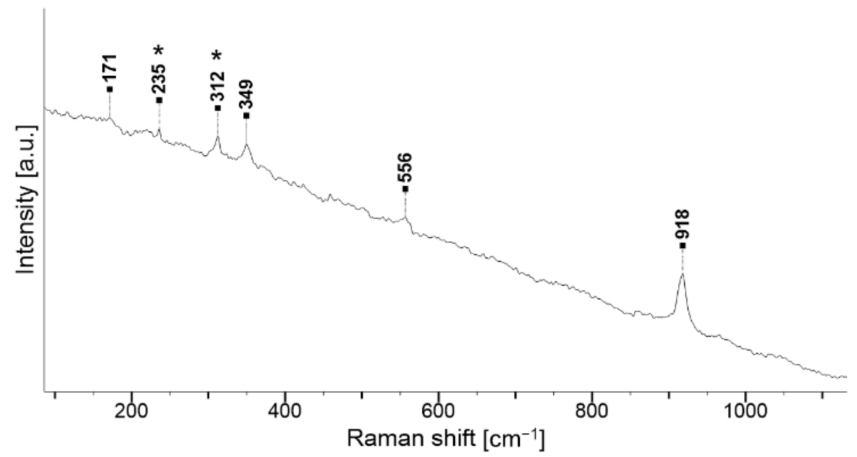

(b)

Figure 15. Inclusions in garnet G5 of fibulae NA806 and G2 of fibulae NA892. Reflected light, parallel polars. (a) Inclusions of sillimanite in garnet G5 of fibula NA806; (b) Raman spectrum of fibre-like inclusion in almandine, with band at $235 \mathrm{~cm}^{-1}$, indicative for sillimanite (black asterisk).

Furthermore, brown plate-like inclusions that occurred in garnets (NA246 G2, NA843 G3, NA892 G2) could indicate the presence of biotite (Figure 16a), whereas according to Horváth and Bendó (2011) [32], similar inclusions were attributed to the phosphate mineral xenotime.

In addition, garnet G1 of fibula NA843 and garnet G2 of fibula NA892 showed the presence of transparent spherical grains, $100-400 \mu \mathrm{m}$ in size, which most probably represent fluid or gas inclusions (Figure 16b).

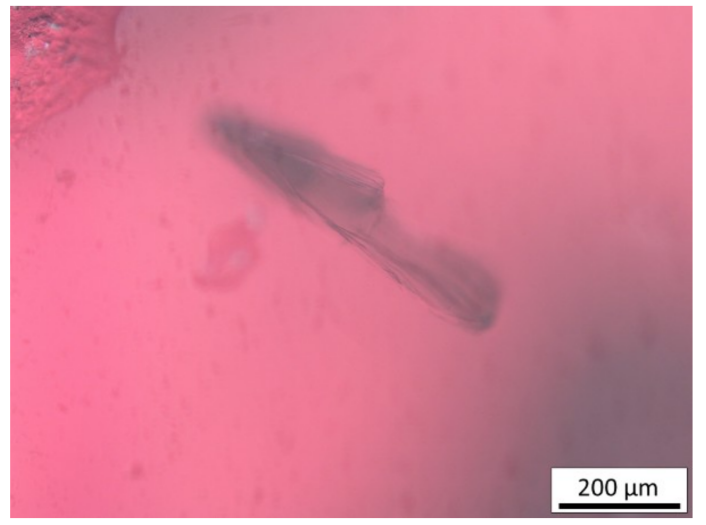

(a)

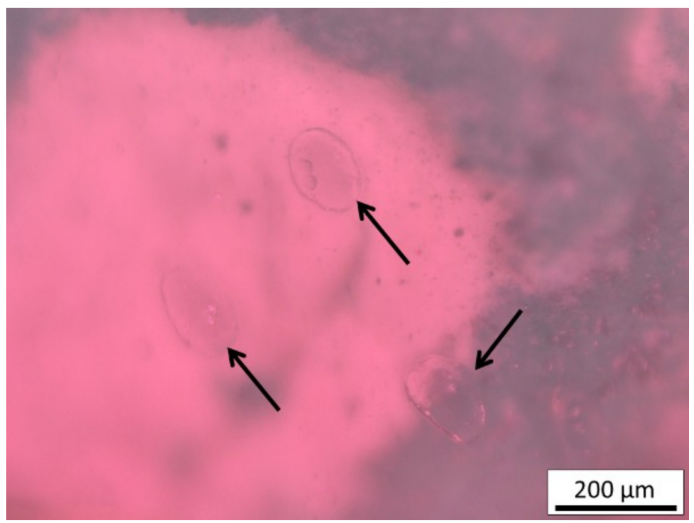

(b)

Figure 16. (a) Brown plate in garnet G2 of fibula NA89.2 Reflected light, parallel polars; (b) Small spherical inclusions in garnet G2 of fibula NA892. Reflected light, parallel polars.

\section{Discussion}

The Raman spectra of garnets obtained in this study all show similar Raman bands indicating almandine as the dominant end member in solid solution. However, shifts of the Raman bands to higher frequencies, e.g., modes assigned to the translation mode of $\mathrm{X}^{2+}$, the rotation mode of $\mathrm{SiO}_{4}$ tetrahedron and the $\mathrm{Si}-\mathrm{O}$ stretching mode, indicate the presence of higher pyrope content in the solid solution for the three garnets. The correlation between the composition of the natural garnets and changes in Raman vibrations was determined in the study of Henderson $(2009)[11,22,26]$. In the case of almandine garnets, Henderson (2009) [11] observed shifts to higher frequencies (the Si-O bending $\left(v_{3}\right)$ at $1044-1047 \mathrm{~cm}^{-1}$, the stretching $\left(v_{4}\right) 636-641 \mathrm{~cm}^{-1}$ and the rotation $\left(\mathrm{R}\left(\mathrm{SiO}_{4}\right)\right)$ modes at $350-357 \mathrm{~cm}^{-1}$ ) with an increase in the pyrope content, although when spessartine content increased in composition, this end member interfered with the linear trend of the increase in all mode frequencies. Similarly, Kuang et al. (2019) [26] observed a linear increase in the frequencies of Si-O stretching and bending, the rotation mode of the tetrahedron $\left(\mathrm{R}_{\left.\left(\mathrm{SiO}_{4}\right)\right)}\right.$ and the translation of the $\mathrm{X}^{2+}$ mode $\left(\mathrm{T}\left(\mathrm{X}^{2+}\right)\right)$ 
with increasing pyrope content and vice versa for the translation of the tetrahedron $\left(\mathrm{T}\left(\mathrm{SiO}_{4}\right)\right)$ when studying synthetic pyrope-almandine garnets, which is consistent to a certain extent (considering the vibration modes) with our results.

According to the observed trends in Raman shifts of vibrational modes in the obtained Raman spectra, the presence of three groups of almandines on the examined S-fibulae was determined, each of which differs in its pyrope content, while spessartine and grossular components were also present in minor amounts. According to similar Fe, Mg, Ca and Mn contents, we classified 16 garnets from the S-fibulae from Groups I and II as Type I almandines (almandines poor in $\mathrm{Mg}, \mathrm{Ca}, \mathrm{Mn}$ ), which showed a shifting of the Raman bands to lower frequencies compared to the three garnets of Group III. Garnets from this group were classified as Type II (almandines rich in $\mathrm{Mg}, \mathrm{Mn}$ ) and characterised with shifting of the Raman bands of certain vibration modes (i.e., $\mathrm{T}\left(\mathrm{X}^{2+}\right)$, Si-O stretching and $\mathrm{R}\left(\mathrm{SiO}_{4}\right)$ ) to higher frequencies due to increased $\mathrm{Mg}$ contents. In comparison to the study of several Slovenian brooches by Šmit et al. (2014) [45], Type I almandine also predominates in S-fibulae and can be combined with Type II almandines, which are also present in minor numbers. Almandines Type II may point to older artefacts of the mid $-5^{\text {th }}$ to $6^{\text {th }}$ century AD, according to Šmit et al. (2014) [45]. Concerning the geographical provenance, as Bimson et al. (1982) [6] first suggested almandines, both of Type I and II, originate from Indian deposits, most likely from Rajasthan or NW India.

In addition, several solid inclusions in garnets from Late Antique jewellery have been observed in works by Calligaro et al. (2002) [4], Horváth and Bendó (2011) [32], which have been systematically classified as Type I and Type II almandine. Apatite, quartz, Fe-oxide minerals, mica and deformed crystals with pleochroic halos, radiation halos or tension fissures can be observed in both garnet types of the examined S-fibulae. In the present study, sillimanite and rutile needles were found only in Type II almandine, which was also reported by Horváth and Bendó (2011) [32] as being more common for Type II almandines.

As far as geological formation is concerned, observed mineral inclusions-apatite, quartz, mica and zircon are common in almandines and can form in different geological environments. They are more common in felsic lithologies, although they also occur in mafic rocks [59]. Sillimanite and rutile are considered important for geological provenance studies as they indicate a smaller range of metamorphic facies [59]. Both are usually associated with medium- to high-grade metamorphism in which rutile is an abundant accessory mineral. According to Force (1980) [61] and Zack et al. (2004) [62], the increasing pressure of the upper amphibolite facies favours rutile formation, but when subjected to low-grade formation, it breaks down to form other titanium bearing phases. Sillimanite is restricted to the medium pressure part of the amphibolite facies and is mostly restricted to granulite facies [63]. Spherical inclusions observed in two garnets of the S-fibulae may indicate the presence of either gas or melt residue. Melt droplets may be entrapped at any phase of garnet recrystallization, especially under rapid heating conditions and disequilibrium melting [64,65]. According to Ferrero et al. (2018) [27], garnet is the most common host for melt inclusions because it is the most widespread peritectic phase resulting from incongruent melting in the continental crust. Since garnets were processed into thin inlays to fit the cloisonné technique of jewellery, some of the inclusions were probably excluded from the host mineral, leaving an inclusion arrangement in the garnets studied incomplete.

As described in the introduction, metamorphic rocks are spatially distributed in the region of NW Indian (Rajasthan), from amphibolite facies of medium-grade metamorphism in the west to granulite facies of high-grade metamorphism in the east, which support the theory of the geological formation of inclusion assemblage in garnets and their probable deposition in the Rajasthan area [33]. Similar rock formations can also be found in parts of East India (Garibpet deposit), where according to Schmetzer et al. (2017) [31], garnets were also excavated in Late Antique times and traded to the west. However, these almandine garnets, which the author has examined, were mainly used and traded as beads. 


\section{Conclusions}

The studied garnets from the S-fibulae of the Slovenian archaeological site Lajh-Kranj (mid-6th century AD) were identified as almandines, determined as Type I and Type II, according to their Raman spectra, chemical characteristics and inclusion assemblage.

Most significant Raman bands were determined in the range of translation mode of $\mathrm{X}^{2+}$ at $169-173 \mathrm{~cm}^{-1}\left(\mathrm{~T}\left(\mathrm{X}^{2+}\right)\right)$, rotation mode of $\mathrm{SiO}_{4}$ tetrahedron at $346-352 \mathrm{~cm}^{-1}\left(\mathrm{R}\left(\mathrm{SiO}_{4}\right)\right)$, Si-O bending mode at 557-559 $\mathrm{cm}^{-1}\left(v_{2}\right)$ and $633-637 \mathrm{~cm}^{-1}\left(v_{4}\right)$, and Si-O stretching mode at 917-919 $\mathrm{cm}^{-1}\left(v_{1}\right)$ and $1042-1045 \mathrm{~cm}^{-1}\left(v_{3}\right)$, which are indicative for almandines. Shifting of Raman bands to higher frequencies were observed for the garnets with enhanced $\mathrm{Mg}$ contents (e.g., for translation mode of $\mathrm{X}^{2+}$ $\left(\mathrm{T}\left(\mathrm{X}^{2+}\right)\right)$ at $\sim 172 \mathrm{~cm}^{-1}$, rotation mode of $\mathrm{SiO}_{4}$ tetrahedron at $\sim 350 \mathrm{~cm}^{-1}\left(\mathrm{R}\left(\mathrm{SiO}_{4}\right)\right)$, $\mathrm{Si}-\mathrm{O}$ bending mode at $\sim 636 \mathrm{~cm}^{-1}\left(v_{4}\right)$, and $\mathrm{Si}-\mathrm{O}$ stretching mode at $\left.\sim 1045 \mathrm{~cm}^{-1}\left(v_{3}\right)\right)$, especially evident for almandines of Type II. Garnets of both types show similar inclusion assemblage with apatite, quartz, crystals with radiation or tension damages (e.g., zircon), ilmenite and mica. Rutile and sillimanite were only found in almandines of Type II. Melt or gas inclusions were also observed in two garnets, although their chemistry cannot be identified.

Specific mineral inclusion assemblage, with emphasis on rutile and sillimanite, imply the origin of garnets in metamorphic rocks of amphibolite or granulite facies. Almandine garnets from the studied S-fibulae are consistent with other studied garnets of Late Antique artefacts found in Slovenia and also in a wider European area of 6th century AD and originating from Indian deposits.

Author Contributions: All authors have read and agree to the published version of the manuscript. J.L. provided the samples; S.K., M.D. and S.D. methodology; S.K. conducted the measurements; S.K., M.D. and S.D. data processing; S.D. writing — original draft preparation; M.D., J.L. and S.D. writing—review and editing; M.D. funding acquisition; S.K. and S.D. wrote the paper.

Funding: This work was financially supported by the Slovenian Research Agency Programme Groups P2-0273 and P1-0195.

Acknowledgments: We wish to thank mag. Nataša Nemeček, senior conservator-restorer, for providing us with the artefacts from National Museum of Slovenia archives.

Conflicts of Interest: The authors declare no conflict of interest.

\section{References}

1. Adams, N. The Garnet Millennium: The Role of Seal Stones in Garnet Studies. In Gems of Heaven: Recent Research on Engraved Gemstones in Late Antiquity c. AD 200-600. Research Publication; Adams, N., Entwistle, C., Eds.; British Museum: London, UK, 2011; Volume 177, pp. 10-24.

2. Scukin, M.; Bazan, I. L'origine du style cloisonné de l'époque des Grandes Migrations. In La Noblesse et Les Chefs Barbares du IIIe au VIIe Siècle: Mémoires Publiés par l'Association Française d'Archéologie Mérovingienne $V$; Vallet, F., Kazinski, M., Eds.; Association Française D'archéologie Mérovingienne; Société des amis du Musée des Antiquités Nationales: Rouen, France, 1993; pp. 63-69.

3. Mathis, F.; Vrielynck, O.; Laclavetine, K.; Chêne, G.; Strivay, D. Study of the provenance of Belgian Merovingian garnets by PIXE at IPNAS cyclotron. Nucl. Instrum. Methods Phys. Res. B 2008, 266, 2348-2352. [CrossRef]

4. Calligaro, T.; Colinart, S.; Poirot, J.-P.; Sudres, C. Combined external-beam PIXE and $\mu$-Raman characterisation of garnets used in Merovingian jewellery. Nucl. Instrum. Methods Phys. Res. B 2002, 189, 320-327. [CrossRef]

5. Farges, F. Mineralogy of Louvres Merovingian garnet cloisonné jewelry: Origins of the gems of the first kings of France. Am. Mineral. 1998, 83, 323-330. [CrossRef]

6. Bimson, M.; La Neice, S.; Leese, M. The characterisation of mounted garnets. Archaeometry 1982, 24, 51-58. [CrossRef]

7. Quast, D.; Schüssler, U. Mineralogische Untersuchungen zur Herkunft der Granate merowingerzeitlicher Cloisonnéarbeiten. Germania 2000, 78, 75-96.

8. Gilg, H.A.; Gast, N.; Calligaro, T. Vom Karfunkelstein. In Karfunkelstein und Seide: Neue Schätze aus Bayerns Frühzeit; Wamser, L., Ed.; Friedrich Pustet Verlag: München, Germany, 2010; pp. 87-100. 
9. Bugoi, R.; Oanta-Marghitu, R.; Calligaro, T. IBA investigations of loose garnets from Pietroasa, Apahida and Cluj-Someseni treasures (5th century AD). Nucl. Inst. Methods Phys. Res. Sect. B 2015, 371, 401-406. [CrossRef]

10. Thoresen, L. Archaeogemmology and Ancient Literary Sources on Gems and their Origins. In Gemstones in the First Millennium AD: Mines, Trade, Workshops and Symbolism; Greiff, S., Hilgner, A., Quast, D., Eds.; Römisch Germanisches Zentralmuseum: Mainz, Germany, 2017; pp. 155-218.

11. Henderson, R.R. Determining Chemical Composition of the Silicate Garnets Using Raman Spectroscopy. Master's Thesis, The Univeristy of Arizona, Tuscon, AZ, USA, 2009.

12. Dubessy, J.; Caumon, M.-C.; Rull Pérez, F. Raman Spectroscopy Applied to Earth Sciences and Cultural Heritage: University Textbook; Dubessy, J., Caumon, M.-C., Rull Pérez, F., Eds.; European Mineralogical Union: London, UK, 2012.

13. Smith, G.D.; Clark, J.H.R. Raman microscopy in archaeological science. J. Archaeol. Sci. 2004, 31, 1137-1160. [CrossRef]

14. Stockton, C.M.; Mason, D.V. A Proposed New Classification for Gem-Quality Garnets. Gems. Gemol. 1985, 21, 205-218. [CrossRef]

15. Will, T.M. Thermodynamics of solid solutions. In Phase Equilibria in Metamorphic Rocks: Thermodynamic Background and Petrological Applications; Springer: Berlin, Germany, 1998; pp. 5-17.

16. Merli, M.; Callegari, A.; Cannllo, E.; Caucia, F.; Leona, M.; Oberti, R.; Ungaretti, L. Crystal-chemical complexity in natural garnets: Structural constraints on chemical variability. Eur. J. Mineral. 1995, 7, 1239-1249. [CrossRef]

17. Grew, E.; Locock, A.; Mills, S.J.; Galuskina, I.; Galuskin, E.; Hålenius, U. IMA Report Nomenclature of the garnet supergroup. Am. Mineral. 2013, 98, 785-811. [CrossRef]

18. Kloprogge, J.T. Infrared and Raman spectroscopy of minerals and inorganic materials. In Encyclopedia of Spectroscopy and Spectrometry, 3rd ed.; Lindon, J.C., Tranter, G.E., Koppenaal, D.W., Eds.; Elsevier: Amsterdam, The Netherlands, 2017; Volume 1, pp. 274-276.

19. Krippner, A.; Meinhold, G.; Morton, A.C.; Eynatten, H. Evaluation of garnet discrimination diagrams using geochemical data of garnets derived from various host rocks. Sediment. Geol. 2014, 306, 36-52. [CrossRef]

20. Mingsheng, P.; Mao, H.K.; Dien, L.; Chao, E.C.T. Raman spectroscopy of garnet-group minerals. Chin. J. Geochem. 1994, 13, 176-183. [CrossRef]

21. Pinet, M.; Smith, D.C. Raman microspectrometry ofgarnets X3Y2Si3O12: 1. The natural calcic series uvarovite-grossular-andradite. Schweiz. Mineral. Petrogr. Mitt. 1993, 73, 21-40.

22. Pinet, M.; Smith, D.C. Raman microspectrometry of garnets $\mathrm{X}_{3} \mathrm{Y}_{2} \mathrm{Z}_{3} \mathrm{O}_{12}$ 2. The natural aluminium series pyrope-almandine-spessartine. Schweiz. Mineral. Petrogr. Mitt. 1994, 74, 161-179.

23. Smith, D.C. The RAMANITAC method for non-destructive and in situ semi-quantitative chemical analysis of mineral solid-solutions by multidimensional calibration of Raman wavenumber shifts. Spectrochim. Acta A Mol. Biomol. Spectrosc. 2005, 61, 2299-2314. [CrossRef]

24. Gilg, H.A.; Gast, N. Determination of titanium content in pyrope by Raman spectroscopy. J. Raman Spectrosc. 2016, 47, 486-491. [CrossRef]

25. Geiger, C.A. A tale of two garnets: The role of solid solution in the development toward a modern mineralogy. Am. Mineral. 2016, 101, 1735-1749. [CrossRef]

26. Kuang, Y.; Xu, J.; Li, B.; Ye, Z.; Huang, S.; Chen, W.; Zhang, D.; Zhou, W.; Ma, M. Crystal-Chemical Properties of Synthetic Almandine-Pyrope Solid Solution by X-Ray Single-Crystal Diffraction and Raman Spectroscopy. Crystals 2019, 9, 541. [CrossRef]

27. Ferrero, S.; Angel, R.J. Micropetrology: Are Inclusions Grains of Truth? J. Petrol. 2018, 59, 1671-1700. [CrossRef]

28. Gems-inclusions all about inclusions in gemstones. Inclusions types-By time of entrapment. Available online: https://www.gems-inclusions.com/inclusions-types/by-type-of-trapping/for-solid-inclusions-2/ (accessed on 20 August 2019).

29. Yardley, B.W.D.; Mackenzie, W.S.; Guilford, C. Atlas of metamorphic rocks and their textures. Terra Nova 1991, 3, 217-218. [CrossRef]

30. Gem-A, The Gemmological Association of Great Britain. News \& Publication: The Source of Garnets Found at the Arikamedu Archaeological Site in South India. Available online: https:/gem-a.com/news-publications/news-blogs/journal-digests/journal/the-source-of-garnetsfound-at-the-arikamedu-archaeological-site-in-south-india (accessed on 20 August 2019). 
31. Schmetzer, K.; Gilg, H.A.; Schussler, U.; Panjikar, J.; Calligaro, T.; Perin, P. The Linkage between garnets found in India at the Arikamedu archaeological site and their source at the Garibpet deposit. J. Gemm. 2017, 35, 598-627. [CrossRef]

32. Horváth, E.; Bendő, Z. Provenance study on a collection of loose garnets from a gepidic period grave in Northeast Hungary. Archeometriai Muh. 2011, 8, 17-32.

33. Kataria, P. Book review: Geology of Rajasthan: Status and perspective. J. Geol. Soc. India 2000, 55, 452-453.

34. Rameshchandra Phani, P. Mineral Resources of Telangana State, India: The Way Forward. Int. J. Innov. Res. Sci. Eng. Technol. 2014, 3, 15450-15459. [CrossRef]

35. Suomen Geologinen Seura-Geologiska Sällskapet i Finland, The Geological Society of Finland. Articles in press, 1980, 52. Available online: http://www.geologinenseura.fi/bulletin/Volume52/index.html (accessed on 20 August 2019).

36. Maharaj, D. Chemical Classification of Gem Garnets. Master's Thesis, University of Pretoria, Pretoria, South African, November 2015.

37. Min-dat.org-Portugal. Available online: https://www.mindat.org/loc-14425.html (accessed on 27 January 2020).

38. Caincross, B. Geology of East Africa. In Minerals $\mathcal{E}$ Gemstones of East Africa; Struik Nature: Cape Town, South Africa, 2019.

39. Lux, J.; Ravnik, J. Poskus rekonstrukcije obsega poznoantičnega grobišča Lajh v Kranju. Varst. Spomenikov 2008, 43-69.

40. Stare, V.; Stopar, B.; Žgur, A.; Goričan, A.; Čenčič, L.; Habič, S.; Petru, P.; Vinski, Z.; Kiszely, I. Kranj: Nekropola iz Časa Preseljevanja Ljudstev; Narodni Muzej: Ljubljana, Slovenia, 1980.

41. Inštitut za arheologijo ZRC SAZU. Strani za študente arheologije zgodnjega srednjega veka na FF v Ljubljani; Poznoantično obdobje. Available online: http://iza.zrc-sazu.si/ff/slavko/pa_grobisca.html (accessed on 10 December 2019).

42. Milavec, T. Prispevek h kronologiji S-fibul v Sloveniji. Arheol. Vestn. 2007, 58, 333-355.

43. Gregorietti, G. Jewelry through the Ages; Hamlyn: London, UK, 1970; p. 139.

44. Kramar, S.; Dolenec, M.; Lux, J. Characterisation of 6th century fibulae with gem materials (cementary Lajh in Kranj, Slovenia) by means of XRF and micro-Raman spectroscopy. In Proceedings of the 6th International Congress on the Application of Raman Spectroscopy in Art and Archaeology, Parma, Italy, 5-8 September 2011; Timeo: Bologna, Italy, 2011; pp. 172-173.

45. Šmit, Ž.; Fajfar, H.; Jeršek, M.; Knific, T.; Lux, J. Analysis of garnets from the archaeological sites in Slovenia. Nucl. Inst. Methods Phys. Res. Sect. B 2014, 328, 89-94. [CrossRef]

46. Nemeček, N.; Kramar, S.; Podobnik, T. Interdisciplinarni pristop-Konserviranje-restavriranje, naravoslovne preiskave in arheološka interpretacija dveh zaponk z grobišča Lajh. In Konservator-Restavrator: Povzetki Strokovnega Srečanja 2016; Nemeček, N., Ed.; Skupnost Muzejev Slovenije, Društvo Restavratorjev Slovenije: Ljubljana, Slovenia, 2016; p. 55.

47. Sibi, N.; Subodh, G. Structural and microstructural correlations of physical properties in natural almandine-pyrope solid solution: $\mathrm{Al}_{70} \mathrm{Py}_{29}$. J. Electron. Mater. 2017, 46, 6947-6956. [CrossRef]

48. Kolesov, B.; Geiger, A.C. Raman spectra of silicate garnets. Phys. Chem. Miner. 1998, 25, 142-151. [CrossRef]

49. Scholz, R.; Frost, R.L.; Xi, Y.; Graça, L.M.; Lagoeiro, L.; López, A. Vibrational spectroscopic characterization of the phosphate mineral phosphophyllite- $\mathrm{Zn}_{2} \mathrm{Fe}\left(\mathrm{PO}_{4}\right)_{2} \cdot 4 \mathrm{H}_{2} \mathrm{O}$, from Hagendorf Süd, Germany and in comparison with other zinc phosphates. J. Mol. Struct. 2013, 1039, 22-27. [CrossRef]

50. Lafuente, B.; Downs, R.T.; Yang, H.; Stone, N. The power of databases: The RRUFF project. In Highlights in Mineralogical Crystallography; Armbruster, T., Danisi, R.M., Eds.; W. De Gruyter: Berlin, Germany, 2015; pp. 1-30.

51. Tan, W.; Wang, C.; He, H.; Xing, C.; Liang, X.; Dong, H. Magnetite-rutile symplectite derived from ilmenite-hematite solid solution in the Xinjie Fe-Ti oxide-bearing, mafic-ultramafic layered intrusion (SW China). Am. Mineral. 2015, 100, 2348-2351. [CrossRef]

52. Tan, W.; He, H.; Wang, C.; Dong, H.; Liang, X.; Zhu, J. Magnetite exsolution in ilmenite from the Fe-Ti oxide gabbro in the Xinjie intrusion (SW China) and sources of unusually strong remnant magnetization. Am. Mineral. 2016, 101, 2759-2767. [CrossRef]

53. Eppler, W.F. The Origin of Healing Fissures in Gemstones. J. Gemm. 1959, 7, 40-66. [CrossRef] 
54. Alex Strekeisen. Plutonic Rocks, Pleochroic halo. Available online: http://www.alexstrekeisen.it/english/ pluto/pleochroichalo.php (accessed on 20 August 2019).

55. Nasdala, L.; Wenzel, M.; Vavra, G.; Irmer, G.; Wenzel, T.; Kober, B. Metamictisation of natural zircon: Accumulation versus thermal annealing of radioactivity-induced damage. Contrib. Mineral. Petrol. 2002, 143, 767-768. [CrossRef]

56. Nasdala, L.; Akhmadaliev, S.; Artac, A.; Chanmuang, N.C.; Habler, G.; Lenz, C. Irradiation effects in monazite-(Ce) and zircon: Raman and photoluminescence study of Au-irradiated FIB foils. Phys. Chem. Miner. 2018, 45, 855-871. [CrossRef]

57. United ID RAMAN LAB. Applications/Solutions: Gemstones. Raman Spectroscopic Inspection and Analysis of Zircon Inclusion in Corundum-Effect of Heat Treatment on Zircon Inclusion. Available online: https: //static1.squarespace.com/static/55e5983ee4b043c85db4fd4c/t/5d1e1fd511031d0001ec94a3/1562255322783/ Raman+Spectroscopic+Inspection+and+Analysis+of+Zircon+Inclusion+in+Corundum.pdf (accessed on 21 March 2020).

58. Tlili, A.; Smith, D.C.; Beny, J.M.; Boyer, H. A Raman microprobe study of natural micas. Mineral. Mag. 1989, 53, 165-179. [CrossRef]

59. Schönig, J.; Meinhold, G.; von Eynatten, H.; Lünsdorf, N.K. Provenance information recorded by mineral inclusions in detrital garnet. Sediment. Geol. 2018, 376, 32-49. [CrossRef]

60. Calligaro, T. Probing Works of Art with Photons and Charged Particles. In Spectroscopy of Emerging Materials; Faulques, E.C., Perry, D.L., Yeremenko, A.V., Eds.; NATO Science Series II: Mathematics, Physics and Chemistry; Springer: Dordrecht, Germany, 2004; Volume 165.

61. Force, E.R. The provenance of rutile. J. Sediment. Res. 1980, 50, 485-488.

62. Zack, T.; von Eynatten, H.; Kronz, A. Rutile geochemistry and its potential use in quantitative provenance studies. Sediment. Geol. 2004, 171, 37-58. [CrossRef]

63. Bucher, K.; Frey, M. Petrogenesis of Metamorphic Rocks; Bucher, K., Frey, M., Eds.; Springer: Berlin/Heidelberg, Germany, 2002.

64. Cesare, B.; Salvioli Mariani, E.; Venturelli, G. Crustal anatexis and melt extraction in the restitic xenoliths at El Hoyazo (SE Spain). Mineral. Mag. 1997, 61, 15-27. [CrossRef]

65. Acosta-Vigil, A.; Buick, I.; Hermann, J.; Cesare, B.; Rubatto, D.; London, D.; Morgan, G.B. Mechanisms of crustal anatexis: A geochemical study of partially melted metapelitic enclaves and host dacite, SE Spain. J. Petrol. 2010, 51, 785-821. [CrossRef] 